\title{
On the Crystal Structure of the Antimony Oxychloride $\mathrm{Sb}_{4} \mathrm{O}_{5} \mathrm{Cl}_{2}$ and Isomorphous Oxybromide
}

\author{
MAJA EDSTRAND
}

Institute of General and Inorganic Chemistry, University of Stockholm, Stockholm, Sweden

\begin{abstract}
X-ray crystallography and electron diffraction have shown that trivalent

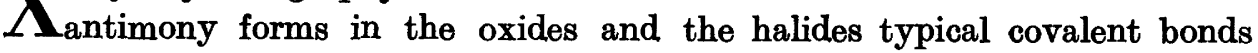
with definite valence angles.

The antimony halides $\mathrm{SbX}_{3}$ form pyramidical molecules, with $\mathrm{Sb}$ at the top of the triangular pyramid and the three $\mathbf{X}$ in the base plane. This was shown by Gregg, Hampson, Jenkins, Jones and Sutton ${ }^{1}$ and by Hassel and Sandbo ${ }^{2}$ by electron diffraction investigations on $\mathrm{SbX}_{3}$ in the gaseous state. Gregg et al. found the following distances $\mathrm{Sb}-\mathrm{X}$ and valence angles $\mathrm{X}-\mathrm{Sb}-\mathrm{X}$ : $\mathrm{SbCl}_{3}: 2.37 \pm 0.02 \mathrm{kX}$ and $104^{\circ} \pm 2^{\circ}, \mathrm{SbBr}_{3}: 2.52 \pm 0.02 \mathrm{kX}$ and $96^{\circ} \pm 2^{\circ}$, $\mathrm{SbI}_{3}: 2.75 \pm 0.02 \mathrm{kX}$ and $98^{\circ} \pm 2^{\circ}$. Hassel and Sandbo found $2.47 \mathrm{kX}$ and $98^{\circ}$ for $\mathrm{SbBr}_{3}$ and $2.70 \mathrm{kX}$ and $99^{\circ}$ for $\mathrm{SbI}_{3}$. Byström and Westgren ${ }^{3}$ have carried out an $\mathrm{X}$-ray analysis on $\mathrm{SbF}_{3}$ in the solid state. Their structure gives the angles of antimony as $81.9^{\circ}$ and $104.3^{\circ}$.

Trivalent antimony forms two types of oxides: the cubic, or low temperature modification, and the orthorhombic, or high temperature modification. They have been investigated by X-ray methods. Cubic $\mathrm{Sb}_{2} \mathrm{O}_{3}$ was first investigated by Bozorth 4 , and was found to be built up from $\mathrm{Sb}_{4} \mathrm{O}_{6}$ molecules. The structure of orthorhombic $\mathrm{Sb}_{2} \mathrm{O}_{3}$ has been determined by Buerger and Hendricks ${ }^{5}$. It is composed of indefinitely long molecular chains of $\left(\mathrm{Sb}_{2} \mathrm{O}_{3}\right)_{\infty}$. The smallest $\mathrm{Sb}-\mathrm{O}$ distances within molecules are all $2.00 \mathrm{kX}$. The valence angles $\mathrm{O}-\mathrm{Sb}-\mathrm{O}$ are $81^{\circ}, 93^{\circ}$, and $99^{\circ}$, and the angles $\mathrm{Sb}-\mathrm{O}-\mathrm{Sb}$ are $116^{\circ}$ and $132^{\circ}$. Later on more exact determinations of the parameters of the cubic $\mathrm{Sb}_{2} \mathrm{O}_{3}$ were made by $\mathrm{Al}$ min and Westgren ${ }^{6}$. They found an $\mathrm{Sb}-\mathrm{O}$ distance of $2.0 \pm 0.1 \mathrm{kX}$, which agrees well with the distance found by Buerger and Hendricks for the orthorhombic form. From Almin and Westgren's values $\mathrm{O}-\mathrm{Sb}-\mathrm{O}$ angles may be calculated as $97.2^{\circ}$ and the $\mathrm{Sb}-\mathrm{O}-\mathrm{Sb}$ angles as $130.5^{\circ}$.
\end{abstract}


In the mineral nadorite, $\mathrm{PbSbO}_{2} \mathrm{Cl}$, however, antimony enters into $\mathrm{MeO}$ layers, where one antimony atom has four oxygen atoms as its nearest neighbours, which indicates an ionic binding ${ }^{7}$. Nadorite is closely related to the $\mathrm{Me}_{2} \mathrm{O}_{2} \mathrm{X}$ compounds which contain trivalent $\mathrm{Bi}$, and which were investigated by Sillén ${ }^{8}$. These compounds form typical layer structures, which contain the same $\mathrm{MeO}$ layers as $\mathrm{BiOX}^{9}$. This suggests that antimony might form oxyhalides of the same types as does bismuth.

It therefore seemed of interest to investigate the oxyhalides of trivalent antimony, in order to obtaine some idea of the bond character of antimony in these compounds.

\section{PREPARATION}

Antimony oxyhalides have been prepared by numerous workers. Among the earlier investigators are Sabanejew $(1871)^{10}$ and Cooke $(1877)^{11}$. A detailed study of the system $\mathrm{Sb}_{2} \mathrm{O}_{3}-\mathrm{HCl}-\mathrm{H}_{2} \mathrm{O}$ was made by Lea and Wood ${ }^{12}$. They examined both the action of hydrochloric acid on hydrated antimonous oxide and the action of water on antimonious chloride. They found $\mathrm{SbOCl}, \mathrm{Sb}_{4} \mathrm{O}_{5} \mathrm{Cl}_{2}$ and $\mathrm{Sb}_{2} \mathrm{O}_{3}$ only to be stable solid compounds. Two metastable compounds were observed. One was assigned the formula $\mathrm{Sb}_{4} \mathrm{O}_{3}(\mathrm{OH})_{5} \mathrm{Cl}$, and $\mathrm{Sb}_{4} \mathrm{O}_{3}(\mathrm{OH})_{3} \mathrm{Cl}_{3}$ was suggested for the other.

In the present investigation solid $\mathrm{SbX}_{3}(\mathrm{X}=\mathrm{Cl}, \mathrm{Br}$, or $\mathrm{I})$ was hydrolysed with various amounts of water either at room temperature or at about $50^{\circ} \mathrm{C}$. In some cases $\mathrm{Sb}_{2} \mathrm{O}_{3}$ was dissolved in $\mathrm{HX}$ and then various amounts of water added. A precipitate was obtained, which crystallised after some time when $\mathrm{X}$ was $\mathrm{Cl}$ or $\mathrm{Br}$. The precipitates were filtered off with suction and dried in an exsiccator with concentrated $\mathrm{H}_{2} \mathrm{SO}_{4}$ or $\mathrm{P}_{2} \mathrm{O}_{5}$ and then washed free from adhering $\mathrm{SbX}_{3} . \mathrm{SbCl}_{3}$ was removed with ether and $\mathrm{SbBr}_{3}$ and $\mathrm{SbI}_{3}$ with carbon disulfide.

It was found that $\mathrm{Sb}_{4} \mathrm{O}_{5} \mathrm{Cl}_{2}$ gave quite good crystals suitable for $\mathrm{X}$-ray investigation. The best crystals were obtained when about $10 \mathrm{~g} \mathrm{SbCl}_{3}$ were dissolved in $20 \mathrm{ml}$ concentrated $\mathrm{HCl}$ and then diluted with 110 to $150 \mathrm{ml}$ water. When this mixture was kept in a conical flask with a stopper at $50^{\circ} \mathrm{C}$, crystals of a size $\leq 1 \mathrm{~mm}$ were obtained within 5 to 10 days. The extension of the crystals was of about the same magnitude in the three dimensions. When the same mixtures were kept at room temperature, crystals appeared only after a very long time. These crystals formed fairly thin plates of a distorted hexagonal shape. After fourteen months plates of a length of more than 5 $\mathrm{mm}$ were obtained. These different types of crystals proved to give identical powder photographs.

It was more difficult to obtain crystals of $\mathrm{Sb}_{4} \mathrm{O}_{5} \mathrm{Br}_{2}$ suitable for $\mathrm{X}$-ray investigation. As a rule they were too small to give good rotation photographs. Sufficiently large crystals were obtained when $\mathrm{Sb}_{2} \mathrm{O}_{3}$ and $\mathrm{HBr}$ were sealed into a glass tube and kept first at about $180^{\circ} \mathrm{C}$ for 10 days and then at room temperature for 18 days.

It seemed of interest to investigate $\mathrm{Sb}_{4} \mathrm{O}_{5} \mathrm{I}_{2}$ at the same time as $\mathrm{Sb}_{4} \mathrm{O}_{5} \mathrm{Cl}_{2}$ and $\mathrm{Sb}_{4} \mathrm{O}_{5} \mathrm{Br}_{2}$, as they might be isomorphous. It would then be possible to obtain more exact information on the positions of the $\mathrm{X}$ atoms from $\mathrm{Sb}_{4} \mathrm{O}_{5} \mathrm{I}_{2}$. I have, however, not yet been able to obtain crystals of $\mathrm{Sb}_{4} \mathrm{O}_{5} \mathrm{I}_{2}$, though such crystals are reported by Cooke ${ }^{11}$. I have tried methods similar to Cooke's and in addition several other methods. On one occasion 
crystals in the form of hexagonal plates appeared and showed hexagonal symmetry from Laue photographs. The Weissenberg photographs were not very good, and a closer investigation and chemical analysis have not yet been carried out.

\section{ANALYSES}

Antimony was determined by titration with $0.1 \mathrm{n} \mathrm{KBrO}_{3}{ }^{*}$. The oxyhalide was dissolved in $25 \% \mathrm{HCl}$ and titrated at about $60^{\circ} \mathrm{C}$ using methyl red as indicator. At the equivalence point the solution was colourless.

Halogen was determined by boiling the oxyhalide with $\mathrm{Na}_{2} \mathrm{CO}_{3}$ solution in a platinum dish. The filtrate was acidified with $\mathrm{HNO}_{3}$ and precipitated by $\mathrm{AgNO}_{3}$. The silver halide was then filtered off, dried, and weighed.

\begin{tabular}{lll} 
& \multicolumn{1}{c}{$\begin{array}{c}\text { Antimony } \\
\%\end{array}$} & \multicolumn{1}{c}{$\begin{array}{c}\text { Halogen } \\
\%\end{array}$} \\
Calc. for $\mathrm{Sb}_{4} \mathrm{O}_{5} \mathrm{Cl}_{2}$ & 76.34 & 11.12 \\
Obs. & $76.0,75.7$ & $11.23,11.15$ \\
Calc. for $\mathrm{Sb}_{4} \mathrm{O}_{5} \mathrm{Br}_{2}$ & 67.01 & 21.99 \\
Obs. & $66.3,66.5$ & $22.34,22.87$
\end{tabular}

\section{UNIT CELL AND SPACE GROUP}

Single crystals of the oxychloride and the oxybromide were picked out and set, and rotation photographs and the following Weissenberg photographs were taken: the photographs $h 0 l, h 1 l, 0 k l, 1 k l, h k 0$, and $h k 1$ for $\mathrm{Sb}_{4} \mathrm{O}_{5} \mathrm{Cl}_{2}$ and the photographs $h 0 l, h 1 l, h k 0$, and $h k 1$ for $\mathrm{Sb}_{4} \mathrm{O}_{5} \mathrm{Br}_{2}$. The compounds proved to be monoclinic.

The cell dimensions were determined more accurately from the powder photographs. Thus

$$
\begin{array}{llll}
a=6.229 & b=5.107 & c=13.50 \mathrm{kX} & \beta=97.27^{\circ} \text { for } \mathrm{Sb}_{4} \mathrm{O}_{5} \mathrm{Cl}_{2} \\
a=6.593 & b=5.133 & c=13.43 \mathrm{kX} & \beta=97.89^{\circ} \text { for } \mathrm{Sb}_{4} \mathrm{O}_{5} \mathrm{Br}_{2}
\end{array}
$$

with an accuracy of about $\pm 0.05 \%$ for the axes, and $\pm 0.05^{\circ}$ for the angles.

If two formula units are assumed per unit cell the density would be:

$$
\begin{array}{llll} 
& & \mathrm{Sb}_{4} \mathrm{O}_{5} \mathrm{Cl}_{2} & \mathrm{Sb}_{4} \mathrm{O}_{5} \mathrm{Br}_{2} \\
d_{\text {calc. }} & 4.94 & 5.33 \\
d_{\text {obs. }} & 4.98,4.94,4.95 & 5.19,5.15,5.25
\end{array}
$$

The agreement is quite good.

- J. M. Kolthoff, Die Massanalyse, Berlin (1928) p. 443. 
(Density determination: A sample was weighed in a small glass bulb, first in air and then in benzene. Air bubbles were driven out by evaporation. The temperature of the benzene was measured at each determination, and the corresponding density of benzene was used.)

In the Weissenberg photographs all reflections $h 0 l$ with $l$ odd, and all reflections $0 k 0$ with $k$ odd are absent. This is characteristic of the space group $\mathrm{C}_{2 \mathrm{~h}}^{5}$. It was observed that all reflections $h 0 l$ with $l=2+4 \mathrm{n}$ are very weak.

\section{STRUCTURE ANALYSIS \\ Patterson analysis}

In order to obtain the positions of the eight antimony atoms of the cell, it seemed appropriate to apply Patterson analysis to $\mathrm{Sb}_{4} \mathrm{O}_{5} \mathrm{Cl}_{2}$, where antimony is much heavier than the other atoms of the cell. The Patterson $x z$-projection and $y z$-projection were calculated. The values of $I(h 0 l)$ and $I(0 k l)$ were estimated visually from the Weissenberg photographs in question. These $I$ values were used instead of the $F^{2}$ values. Spots with large $\Theta$ were not taken into account (cf. Sillén) ${ }^{13}$.

Because of the symmetry of space group $\mathrm{C}_{2 \mathrm{~h}}^{5}$, the parameters need only to be varied within the limits: $0 \leq x \leq 1,0 \leq y \leq \frac{1}{2}$, and $0 \leq z \leq \frac{1}{2}$. If positions $4(e)$ only are considered, it would be possible to make the limits even narrower for one set of parameters, thus for instance: $0 \leq x_{1} \leq \frac{1}{2}$, $0 \leq y_{1} \leq \frac{1}{4}, \quad 0 \leq z_{1} \leq \frac{1}{4}$ and $0 \leq x_{2} \leq 1,0 \leq y_{2} \leq \frac{1}{2}, 0 \leq z_{2} \leq \frac{1}{2}$.

$$
\mathrm{Th}_{j}^{\mathrm{s}} \mathrm{e} x z-\mathrm{p} \text { rojection }
$$

In the $x z$-projection of space group $\mathrm{C}_{2 \mathrm{~h}}^{5}$ the following point positions are possible: $2(\mathrm{a})$ or $2(\mathrm{c}): 00,0 \frac{1}{2} ; 2(\mathrm{~b})$ or $2(\mathrm{~d}): \frac{1}{2} 0, \frac{1}{2} \frac{1}{2} ; 4(\mathrm{e}): \pm(x, z)$, $\pm\left(x, \frac{1}{2}+z\right)$.

The Patterson $x z$-projection actually found is given in fig. 1 , which is referred to during the following discussion.

On account of the symmetry it is necessary to calculate only the area $0 \leq x \leq \frac{1}{2}, 0 \leq z \leq \frac{1}{2}$.

For the eight antimony atoms in the unit cell, all combinations involving twofold positions of different kinds can be excluded, as there is no peak in the projection corresponding to an interatomic vector at $\left(\frac{1}{2} \frac{1}{2}\right)$. On the other hand, two twofold positions of the same kind may be regarded as a special case of 4(e). Therefore, only a combination of two fourfold positions 4(e) need be considered. Thus 


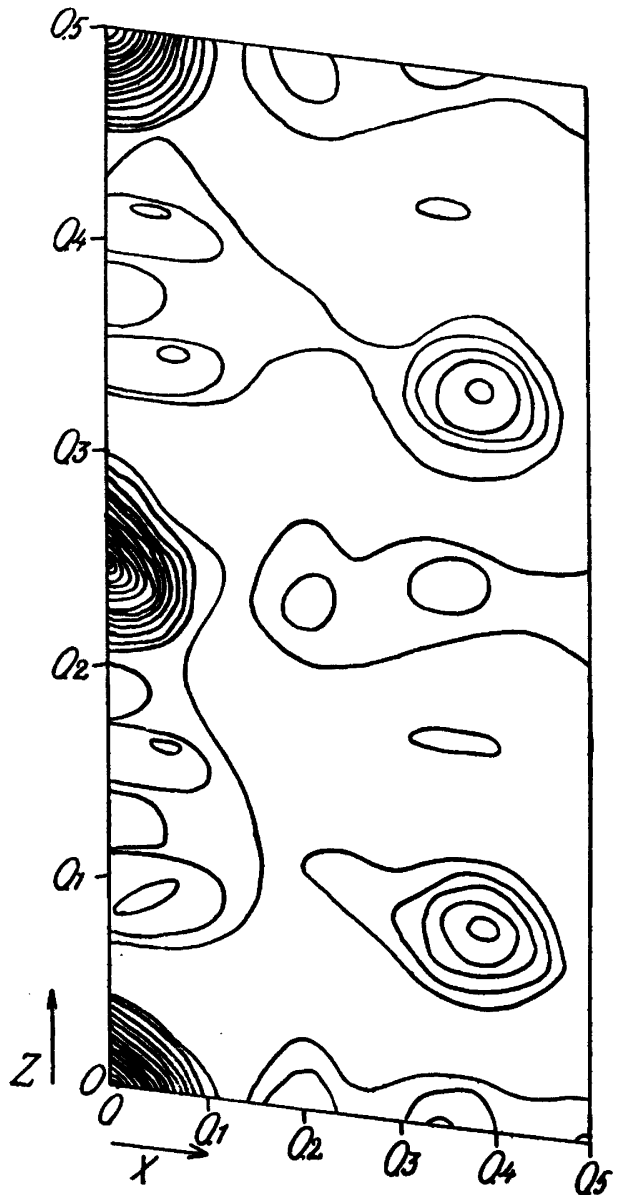

Fig. 1. Patterson projection $P(x p z)$ for $\mathrm{Sb}_{4} \mathrm{O}_{6} \mathrm{Cl}_{\mathbf{2}}$

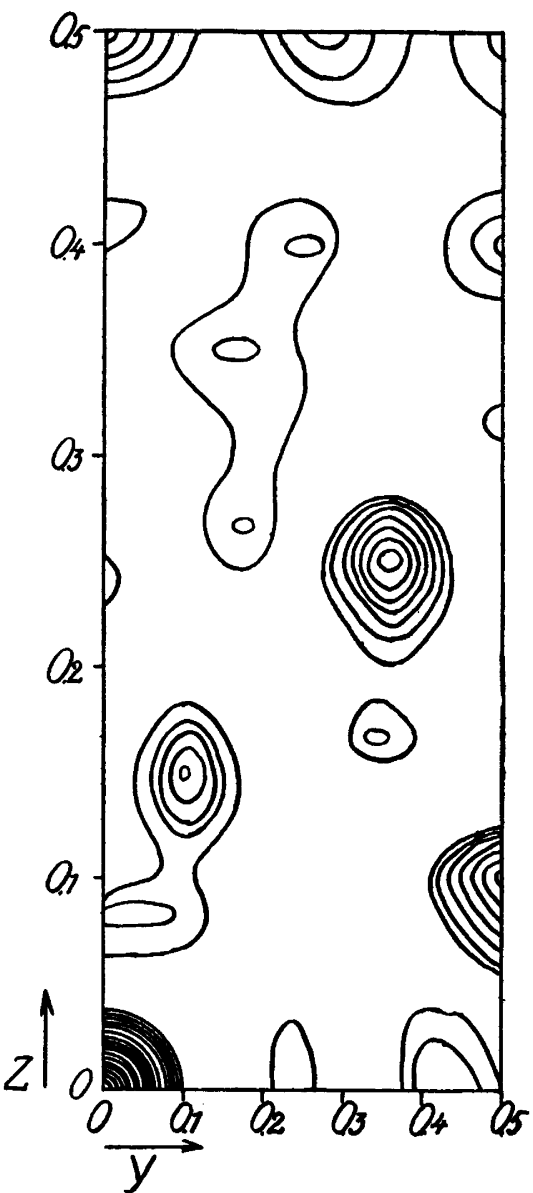

Fig. 2. Patterson projection $P(p y z)$ for $\mathrm{Sb}_{4} \mathrm{O}_{8} \mathrm{Cl}_{2}$.

$$
\begin{aligned}
& 4 \mathrm{Sb}_{1} \text { in } x_{1}, z_{1} \bar{x}_{1}, z_{1} \bar{x}_{1}, \frac{1}{2}-z_{1} x_{1}, \frac{1}{2}+z_{1} \\
& 4 \mathrm{Sb}_{2} \text { in } x_{2}, z_{2} \bar{x}_{2}, \bar{z}_{2} \bar{x}_{2}, \frac{1}{2}-z_{2} x_{2}, \frac{1}{2}+z_{2}
\end{aligned}
$$

Peaks in the Patterson projection corresponding to interatomic vectors can be expected at the following points:

Distances $\mathrm{Sb}_{1}-\mathrm{Sb}_{1}$ and $\mathrm{Sb}_{2}-\mathrm{Sb}_{2}$ :

$$
\begin{gathered}
\text { I of weight } 2 \frac{ \pm\left(2 x_{1}, 2 z_{1}\right)}{ \pm\left(2 x_{2}, 2 z_{2}\right)} \\
\text { II of weight } 2 \frac{ \pm}{ \pm\left(2 x_{1}, 2 z_{1}-\frac{1}{2}\right)} \\
\text { III together of weight } 8 \pm\left(2 x_{2}, 2 z_{2}-\frac{1}{2}\right) \\
\text { I } \left.\frac{1}{2}\right)
\end{gathered}
$$




\section{Distances $\mathrm{Sb}_{1}-\mathrm{Sb}_{\mathbf{2}}$}

$\begin{array}{ll}\text { IV of weight } 4 \begin{array}{l} \pm\left(x_{1}-x_{2}, z_{1}-z_{2}\right) \\ \pm\left(x_{1}+x_{2}, z_{1}+z_{2}\right)\end{array} & \pm\left(x_{1}-x_{2}, z_{1}-z_{2}-\frac{1}{2}\right) \\ & \pm\left(x_{1}+x_{2}, z_{1}+z_{2}-\frac{1}{2}\right)\end{array}$

On inspecting more closely the limits of the parameters necessary to explain a Patterson $x z$-projection of space group $\mathrm{C}_{2 \mathrm{~h}}^{5}$, it was found from the symmetry that only $x$-parameters between 0 and $\frac{1}{2}$ need be considered, and that one $z$-parameter can be limited to $0 \leq z_{2} \leq \frac{1}{4}$ and the other to $0 \leq z_{1} \leq \frac{1}{2}$.

In the region $0 \leq x \leq \frac{1}{2}, 0 \leq z \leq \frac{1}{2}$ two representatives of group $I$ or II, two of group IV and the only vector of III will be found.

With the exception of the two high peaks at $(00)$ and $\left(0 \frac{1}{2}\right)$, the Patterson projection reveals only three high peaks instead of the expected four. One is situated at $\left(0, \frac{1}{4}\right)$ and is almost as high as the peaks at $(0,0)$ and $\left(0, \frac{1}{2}\right)$, which indicates that its weight must be eight. The other two which are lower, are found at $x \approx 0.4, z \approx 0.1$ and $x \approx 0.4, z \approx 0.35$. They have the same height and are therefore assumed to have the weight four. As the $z$-values 0.1 and 0.35 cannot be transformed into each other by $\pm \frac{1}{2}$, both peaks cannot belong to group IV. This shows that $2 x_{1}$ must almost coincide with $+2 x_{2}$ or $-2 x_{2}$. The $x$ values to be considered in the Patterson projection are 0 , $0.4,0.6$, and 1.0.

The peak at $\left(0, \frac{1}{4}\right)$ probably belongs to group IV, which will give it the weight 8 , if $x_{1}-x_{2}=0$ and $2 x_{1} \approx 2 x_{2} \approx 0.4$ or 0.6 , which gives $x_{1} \approx x_{2} \approx$ 0.2 or 0.3 .

If it is assumed that $x_{1}-x_{2}, z_{1}-z_{2}$ is $(0,0,25)$ which gives $z_{1} \approx z_{2}+$ 0.25 , solutions of the following two types are possible:

A. Assuming $x_{1}+x_{2}, z_{1}+z_{2}$ is $(0.4,0.6)$ we have $x_{1} \approx x_{2} \approx 0.2, z_{1} \approx 0.425, z_{2} \approx$ 0.175

B. Assuming $x_{1}+x_{2}, z_{1}+z_{2}$ is $(0.4,0.35)$ we have $x_{1} \approx x_{2} \approx 0.2, z_{1} \approx 0.3, z_{2} \approx 0.05$

From the $y z$-projection it will later on be evident that only solutions of type $B$ are possible.

\section{The $y z-$ projection}

From the $x z$-projection it seems probable that the antimony atoms occupy two fourfold positions $4(e)$. This gives the following point positions in the yz-projection:

$$
\begin{array}{llllll}
4 & \mathrm{Sb}_{1} & y_{1}, z_{1} & \bar{y}_{1}, \bar{z}_{1} & \frac{1}{2}+y_{1}, \frac{1}{2}-z_{1} & \frac{1}{2}-y_{1}, \frac{1}{2}+z_{1} \\
4 \mathrm{Sb}_{2} y_{2}, z_{2} & \bar{y}_{2}, \bar{z}_{2} & \frac{1}{2}+y_{2}, \frac{1}{2}-z_{2} & \frac{1}{2}-y_{2}, \frac{1}{2}+z_{2}
\end{array}
$$


Using the same group notations as in the preceeding section the corresponding maxima in the vector space are:

$$
\begin{array}{rlr} 
& \text { Weight 1 } & \\
\text { I } \pm\left(2 y_{1}, \pm 2 z_{1}\right) & & \pm\left(2 y_{2}, \pm 2 z_{2}\right) \\
& \text { Weight 2 } & \\
& \text { II } \pm\left(\frac{1}{2}, 2 z_{1}+\frac{1}{2}\right) & \pm\left(\frac{1}{2}, 2 z_{2}+\frac{1}{2}\right) \\
\text { III } \pm\left(2 y_{1}+\frac{1}{2}, \frac{1}{2}\right) & \pm\left(2 y_{2}+\frac{1}{2}, \frac{1}{2}\right) \\
\text { IV } \pm\left(y_{1}-y_{2}, \pm\left(z_{1}-z_{2}\right)\right) & \pm\left(\frac{1}{2}+y_{1}-y_{2}, \frac{1}{2} \pm\left(z_{1}+z_{2}\right)\right) \\
& \pm\left(y_{1}+y_{2}, \pm\left(z_{1}+z_{2}\right)\right) & \pm\left(\frac{1}{2}+y_{1}+y_{2}, \frac{1}{2} \pm\left(z_{1}-z_{2}\right)\right)
\end{array}
$$

Just as for the $x z$-projection, it was found that the limits of the parameters for the Patterson $y z$-projection can be made narrower than for the spatial structure. Thus $0 \leq y_{1} \leq \frac{1}{2}, 0 \leq y_{2} \leq \frac{1}{4}, 0 \leq z_{1} \leq \frac{1}{2}$ and $0 \leq z_{2} \leq \frac{1}{4}$.

The Patterson projection was calculated for $0 \leq y \leq \frac{1}{2}, 0 \leq z \leq \frac{1}{2}$. This area should contain eight peaks of weight 2 and two of weight 1 . Now, excluding the high peak at $(0,0)$ the projection contains four peaks, which are much higher than the others, namely at $\left(0, \frac{1}{2}\right),\left(\frac{1}{8}, 0.15\right),\left(\frac{3}{8}, \frac{1}{4}\right),\left(\frac{1}{2}, 0.1\right)$, cf. fig. 2. The height of the last two seems to indicate a weight of 4, which was taken as a starting point.

At $y=\frac{1}{2}$ there are peaks at $z \approx 0.1$ (high), $0.4,0.5,0.6$ and 0.9 (high), which should correspond to vectors of group II. Accordingly, possible values of $z_{1}$ and $z_{2}$ would be about $0,0.05,0.2,0.3,0.45$ or 0.5 . The $x z$-projection could be explained only by assuming $z_{1}-z_{2} \approx 0.25$ or $z_{1}+z_{2} \approx 0.25$ or $0.75 *$. This excludes the $z$-values 0 and 0.5 . The possible $z$-combinations are therefore, $z_{1} \approx 0.05$ or $0.45 z_{2} \approx 0.2$ or 0.3 .

At $z=\frac{1}{2}$ there are peaks at $y \approx 0, \frac{1}{4}, \frac{1}{2}, \frac{3}{4}$ and 1.0 , which should correspond to vectors of group III. This gives $y_{1}$ and $y_{2} \approx 0, \frac{1}{8}, \frac{1}{4}, \frac{3}{8}$, or $\frac{1}{2}$.

The high peak at about $\left(\frac{3}{8}, \frac{1}{4}\right)$, which, according to the possible $\mathrm{z}$-values, must be of group IV and thus contain the sum or the difference between $y_{1}$ and $y_{2}$, indicates a combination of $y \approx \frac{1}{8}$ or $\frac{3}{8}$ with $y \approx 0, \frac{1}{4}$ or $\frac{1}{2}$. As the peaks at $y=\frac{1}{2}$ are not of the same height, it seems probable that one peak of group I coincides with $(0.5,0.1)$ or $(0.5,0.9)$. This would be possible if $y_{1} \approx \frac{1}{4}$. From the previous discussion on the limits of the parameters, it is clear that we need only consider $y_{2} \approx \frac{1}{8}$. The possible combinations are:

$$
\begin{aligned}
& y_{1} \approx \frac{1}{4} \quad z_{1} \approx 0.05 \text { or } 0.45 \\
& y_{2} \approx \frac{1}{8} \quad z_{2} \approx 0.2
\end{aligned}
$$

\footnotetext{
* In the $x z$-projection the possibility of $z_{1}+z_{2} \approx 0.25$ or 0.75 was not' discussed, as this would give $x$-parameters outside the given limits.
} 
As $y_{1}+y_{2} \approx \frac{3}{8}$, the $z$-values 0.25 or 0.75 of the Patterson projeotion must be equal to $\pm\left(z_{1}+z_{2}\right)$. This is only possible if $z_{1} \approx 0.05$ and $z_{2} \approx 0.2$. Thus we obtain: $y_{1} \approx \frac{1}{4} \quad z_{1} \approx 0.05$

$$
y_{2} \approx \frac{1}{8} \quad z_{2} \approx 0.2
$$

Now the parameter values from the two projections have to be combined into a structure in space. As the two Patterson projections can be explained independently the indices of the parameters were chosen arbitrarily. In combining the two projections the numerically equal $z$-values must be taken and not those with the same index. It should also be observed that the limits of the parameters are larger in space than in the Patterson projections. The parameter limits were discussed in the introductory part of the Patterson"analysis. The narrowest space limits need not, of course, all belong to the same fourfold position.

From the $x z$-projection we obtain only two alternatives

$$
\begin{array}{ll}
x_{1} \approx 0.2 & z_{1} \approx 0.3 \\
x_{2} \approx 0.2 & z_{2} \approx 0.05
\end{array} \quad \text { and } \quad \begin{array}{ll}
x_{1} \approx 0.8 & z_{1} \approx 0.2 \\
x_{2} \approx 0.2 & z_{2} \approx 0.05
\end{array}
$$

and from the $y z$-projection only one

$$
\begin{array}{ll}
y_{1} \approx \frac{1}{4} & z_{1} \approx 0.05 \\
y_{2} \approx \frac{1}{8} & z_{2} \approx 0.2
\end{array}
$$

(Other combinations give both $z_{1}$ and $z_{2}$ or both $y_{1}$ and $y_{2}$ larger than 1 ). Thus we obtain as the only possible combination

$$
\begin{aligned}
& x_{1} \approx 0.2 \quad y_{1} \approx \frac{1}{4} \quad z_{1} \approx 0.05 \\
& x_{2} \approx 0.8 \quad y_{2} \approx \frac{1}{8} \quad z_{2} \approx 0.2
\end{aligned}
$$

where the indices are the same as in the $y z$-projection.

\section{DISCUSSION OF INTENSITIES}

In order to get more exact values for the parameters, these were varied around the approximate values obtained from the Patterson analysis, and the intensities were calculated. At first the influence of the halogen and the oxygen atoms was neglected.

For h00 the structure factor is $\frac{F_{\mathrm{Sb}}}{4 f_{\mathrm{Sb}}}=\cos 2 \pi h x_{1}+\cos 2 \pi h x_{2}$. 
As $\left|x_{1}\right| \approx\left|x_{2}\right| \approx 0.2$, it is simpler to write $\xi_{1}=\frac{\left|x_{1}\right|+\left|x_{2}\right|}{2}$ and $\xi_{2}=\frac{\left|x_{1}\right|-\left|x_{2}\right|}{2}$, thus giving $\frac{F_{\mathrm{sb}}}{4 f_{\mathrm{sb}}}=2 \cos 2 \pi h \xi_{1} \cos 2 \pi h \xi_{2}$.

It is possible to fix $\xi_{1}$ to within fairly narrow limits as 0.197 for the oxychloride, whereas $\xi_{2}$ is more difficult to determine. Presumably $0 \leq \xi_{2} \leq 0.015$. At first $\xi_{2}$ was assumed to be 0 .

It is obvious that the antimony atoms are situated in two layers at $x \approx$ 0.2 and $x \approx 0.8$. I thought it then probable that the ten oxygen and the four halogen atoms are also situated in layers, as, for instance, in the $\mathrm{Me}_{2} \mathrm{O}_{2} \mathrm{X}$ compounds investigated by Sillén. Considerations of space as well as a rough intensity calculation of $h 00$ for $\mathrm{Sb}_{4} \mathrm{O}_{5} \mathrm{Br}_{2}$ make it probable that the four halogens are situated at $x \approx \frac{1}{2}$. However, they must occupy a fourfold position, as 2(b) and 2(d) with $x=\frac{1}{2}$ would give a distance halogen - halogen equal to $\frac{1}{2} b$ or about $2.5 \mathrm{kX}$, which seems very improbable. Then there is no room for oxygen atoms at $0.2<x<0.8$. It seems most probable that $x_{0} \approx 0$. The ten oxygen atoms must then occupy one twofold position with $x=0$, and two fourfold positions 4(e).

Assuming $\xi_{2} \approx 0$, all $\mathrm{Br}$ at $x \approx \frac{1}{2}$, and all oxygen at $x \approx 0, \xi_{1}$ was determined to be about 0.181 for the oxybromide. Then the $\mathrm{Br}$ - and the Sb-parameters were varied alternately to obtain the best intensity agreement. When the intensities were calculated from $I \sim \frac{1+\cos ^{2} 2 \Theta}{\sin 2 \Theta} F^{2}$ it proved very difficult to obtain a satisfactory agreement for $I(100)$ and $I(200)$, which are fairly weak and seem to have almost the same intensities. On assuming all the ten oxygens at $x=0, I(200)_{\text {calc. }}$ was much weaker than $I(100)_{\text {calc. The influence }}$ of varying the oxygen $x$-parameters was then examined. It was assumed that the two $x_{0}$ are nearly equal, as the two $x_{\mathrm{Sb}}$ seemed to be equal, and it would be difficult to make separate variations of the former, considering their low contribution to the intensities. The best intensity agreement was obtained with $\xi_{1}=0.185, x_{\mathrm{Br}}=0.515(0.485), 20$ at $x=0$ and 80 at $x=0.11, \xi_{2}$ was assumed to be $=0$.

The $x$-parameters of the oxychloride were then inspected more closely, which led to the conclusion that $\xi_{1}=0.197,0<\xi_{2}<0.01, x_{\mathrm{cl}}=0.515$ $(0.485)$ and 20 at $x=0,80$ at $x=0.13$.

For $00 l$ the structure factor is

$$
\frac{F_{\mathrm{sb}}}{4 f_{\mathrm{sb}}}=\cos 2 \pi l z_{1}+\cos 2 \pi l z_{\mathrm{s}}
$$


As the $y$ - and the $z$-axes of $\mathrm{Sb}_{4} \mathrm{O}_{5} \mathrm{Br}_{2}$ are almost equal to those of $\mathrm{Sb}_{4} \mathrm{O}_{5} \mathrm{Cl}_{2}$, it was assumed that the $y$-and $z$-parameters of the two compounds are nearly equal. Considering antimony only, the best agreement was preliminarily obtained with $z_{1}=0.049$ and $z_{2}=0.201$ for the oxychloride. As the reflections $h 0 l$ with $l=2+4 \mathrm{n}$ are very weak for both the oxychloride and the oxybromide, it was assumed that the halogens cannot contribute much to these reflections. This would indicate $z_{\text {hal. }} \approx \frac{1}{8}$.

To determine the $y$-parameters of $\mathrm{Sb}$ more accurately, the reflections $0 k l$ from a Weissenberg photograph of $\mathrm{Sb}_{4} \mathrm{O}_{5} \mathrm{Cl}_{2}$ were used, as the few reflections $0 k 0$ were not sufficient. Assuming $y_{1}=\frac{1}{4}$ and $y_{2}=\frac{1}{8}$ we have $I(043)_{\text {calc }} \sim 0$. As the observed intensity is between medium and strong, this reflection cannot depend only on $\mathrm{Cl}$ and $\mathrm{O}$. The best agreement was obtained with $y_{1}=0.225$ and $y_{2}=0.113$.

The $h k 0$ reflection of $\mathrm{Sb}_{4} \mathrm{O}_{5} \mathrm{Br}_{2}$ were then scrutinized. Here the contribution of $\mathrm{Br}$ to the intensities cannot be entirely neglected. A variation in the $y$-parameters of $\mathrm{Sb}$ indicates $y_{1 \mathrm{Sb}}=0.220$ and $y_{2 \mathrm{Sb}}=0.12$, when considering $0 k 0$ reflections, if it is assumed at the same time (1) that $F_{\mathrm{Br}} \approx-F_{\mathrm{Sb}}$ for 040 , which is absent, and $F_{\mathrm{Br}} \approx 0$ for 060 , and (2) that $F_{\mathrm{Br}}$ and $F_{\mathrm{Sb}}$ have the same sign (negative) for 020 . It seemed desirable to obtain as high a calculated intensity of 020 as possible. Values of $y_{\mathrm{Br}}$ fulfilling the conditions (1) are approximately $0.045,0.205,0.295,0.455,0.545,0.705,0.795$ and 0.955 . Of these values only $0.205,0.295,0.705$ and 0.795 fulfil condition (2). If $y_{\text {hal, }} \approx 0.205$ and 0.295 are used for the oxychloride, and at the same time we assume $z_{\mathrm{cl}} \approx \frac{1}{8}, x_{\mathrm{cl}} \approx \frac{1}{2}$, a distance $2.1 \mathrm{kX}$ (with more preliminary parameters $1.9-2.0 \mathrm{kX}$ ) is obtained for $\mathrm{Sb}-\mathrm{Cl}$, which is too small, as $\mathrm{Sb}-\mathrm{Cl}$ is $2.37 \pm 0.02 \mathrm{kX}$ in $\mathrm{SbCl}_{3}{ }^{1}$. These $y$-values were therefore rejected.

It is not possible to distinguish between $y_{\mathrm{Br}}=0.705$ and 0.795 by means of $h k 0$. It is, however, possible to do so by means of $h k l$ with $l$ odd. When the other parameters were more definitely fixed, the influence of oxygen is, however, of little importance, a comparison was made between $I(012)$ and $I(013)$. $I(012)_{\text {obs }}$ was stronger than $I(013)_{\text {obs. }}$. Taking the polarizing factor into account, the calculated values were:

$$
\begin{aligned}
& \text { 1. } y_{\mathrm{Br}}=0.705: I(012) \sim 17.1, I(013) \sim 8.6 . \\
& \text { 2. } y_{\mathrm{Br}}=0.795: I(012) \sim 17.1, I(013) \sim 25.6 .
\end{aligned}
$$

This favours $y=0.705$. When fixing the oxygen atoms, space considerations also seemed to favour $y=0.705$. 


\section{THE OXYGEN POSITIONS}

The rough parameter values of antimony and halogen were now used to determine the oxygen positions, which would render possible a more exact calculation of the parameters.

The $\mathrm{Sb}-\mathrm{O}$ distance was assumed to be the same as in $\mathrm{Sb}_{2} \mathrm{O}_{3}$, where it is $2.0 \mathrm{kX},(c f . p .178)$, and the sum of the ionic radii of oxygen and halogen are:

\begin{tabular}{|c|c|c|c|c|}
\hline $\mathrm{O}-\mathrm{Cl}$ & 3.1 & (Goldschmidt), & 3.21 & kX (Paulin \\
\hline $\mathrm{O}-\mathrm{Br}$ & 3.28 & $\Delta$ & 3.35 & " \\
\hline-0 & 2.64 & $\Rightarrow$ & 2.80 & ) \\
\hline
\end{tabular}

(Values of ionic radii are taken from Internationale Tabellen ${ }^{14}$.)

Spheres of appropriate radii, inside which no oxygen ions could occur, were then drawn around the $\mathrm{Sb}$ and $\mathrm{Cl}(\mathrm{Br})$ centers, and cuts were made at $x=0$ and $x=0.13$ (chloride) $x=0.11$ (bromide), since these $x$-parameters seemed probable for oxygen from the intensities of $h 00$.

Cut $x=0$. There are two twofold positions with $x=0,2(a):(000),\left(0 \frac{1}{2} \frac{1}{2}\right)$ and 2(c): $\left(00 \frac{1}{2}\right),\left(0 \frac{1}{2} 0\right)$. This cut shows that only $2(\mathrm{c})$ is possible. It also seems as if some $\mathrm{O}-\mathrm{O}$ distances would be rather short, if all oxygen atoms were placed at $x=0$.

Cut $x=0.11(0.72 \mathrm{kX}$ ) (bromide). Fig. 3 (The coordinates are referred to an orthogonal coordinate system, where the directions of the $y$ - and the $z$-axis of the monoclinic cell and the orthogonal system coincide.) Possible oxygen

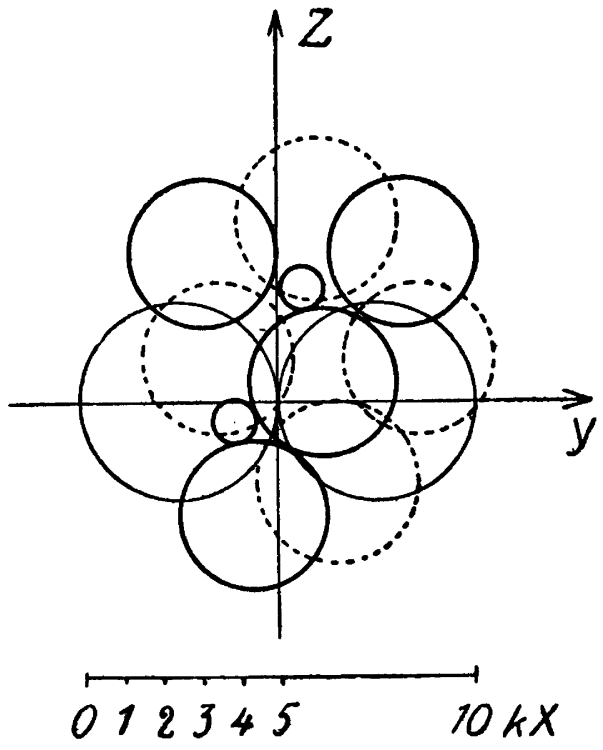

Fig. 3. $\mathrm{Sb}_{4} \mathrm{O}_{8} \mathrm{Br}_{2}$. Spheres of appropriate radii are drawn around the $S b, B r$, and $O$ centers. Cut at $x=0.11$. Thick circle $=$ the $S b . \mathrm{O}$ distance, dotted circle $=$ the $\mathrm{Br}-\mathrm{O}$ distance and thin circle $=$ the $O . O$ distance. Possible oxygen positions are approximatly: I $y-0.3 k x \quad z \approx-0.9 k x$, II $y \approx O$, $z \approx 3 k x$ and $I I I y \approx 1.5 k x z \approx 2.5 k x$. 
positions are approximately I. $y \approx-0.3 \mathrm{kX}, z \approx-0.9 \mathrm{kX}$, II. $y \approx 0, z \approx$ $3 \mathrm{kX}$ and III. $y \approx 1.5 \mathrm{kX}, z \approx 2.5 \mathrm{kX}$. It does not seem possible to combine II and III. With the preliminary coordinates there would be a distance $0-0$ about $1.6 \mathrm{kX}$. The oxygen can, however, be moved, so that this distance will become larger or about $2.25 \mathrm{kX}$. It might be possible to make it even larger, but this does not seem to be of interest, as these oxygen positions appear to give a rather improbable coordination around $\mathrm{Sb}_{1}$. It is seen from fig. 4 that between two adjacent $\mathrm{Sb}_{1}$ (distance between them $3.4 \mathrm{kX}$ ) there are no other negative charges than $\mathrm{Br}$ at distances 3.3 and $3.5 \mathrm{kX}$.
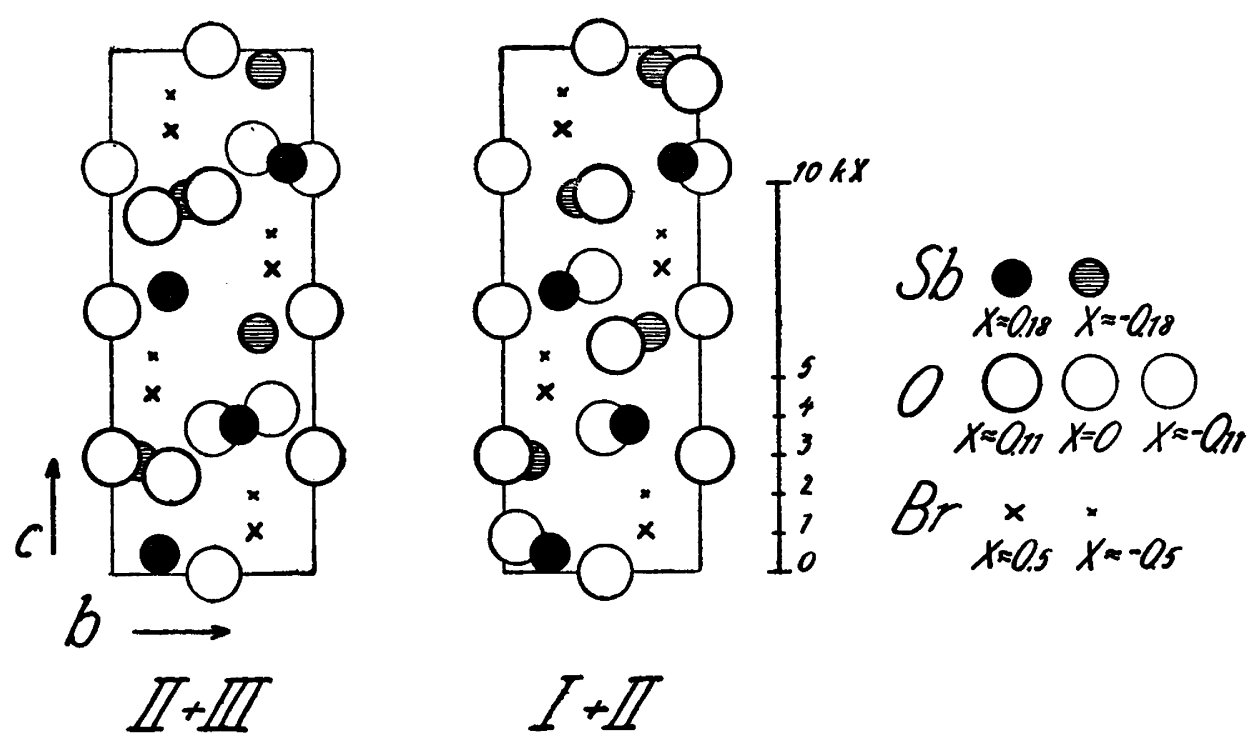

Fig. 4. Orthogonal projections of the unit cell of $\mathrm{Sb}_{4} \mathrm{O}_{5} \mathrm{Br}_{2}$, giving the possible oxygen positions which could later on be excluded.

This would mean that only a combination of I and II or I and III is possible. Now the distance between two oxygen atoms of $\mathrm{O}_{\mathrm{I}}$ would be about $2.4 \mathrm{kX}$, which seems rather short. If $\mathrm{O}_{\mathrm{I}}$ is moved to $x \approx 0.6, y \approx 0.2$ and $z \approx-1.2$ $\mathrm{kX}$, this distance will be better (about $2.7 \mathrm{kX}$ ), though the distance $\mathrm{O}_{\mathrm{I}}-\mathrm{Br}$ will be a little short. This was however thought to be less objectionable, as the halogens are more easily deformed. If $\mathrm{I}$ is combined with II the $\mathrm{O}-\mathrm{O}$ distance of two adjacent oxygens of $I$ and II would be about $2.6 \mathrm{kX}$, if the coordinates $x \approx 0.72, \mathrm{y} \approx-0.3, z \approx-0.9 \mathrm{kX}$ are used for $\mathrm{O}_{\mathrm{I}}$, and about 2.2 $\mathrm{kX}$ with the coordinates $x \approx 0.6, y \approx 0.2, z \approx-1.2 \mathrm{kX}$. There seems to be some difficulty in obtaining good $\mathrm{O}-\mathrm{O}$ distances with a combination of $\mathrm{I}$ and II. A projection of this configuration is shown in fig. 4. 


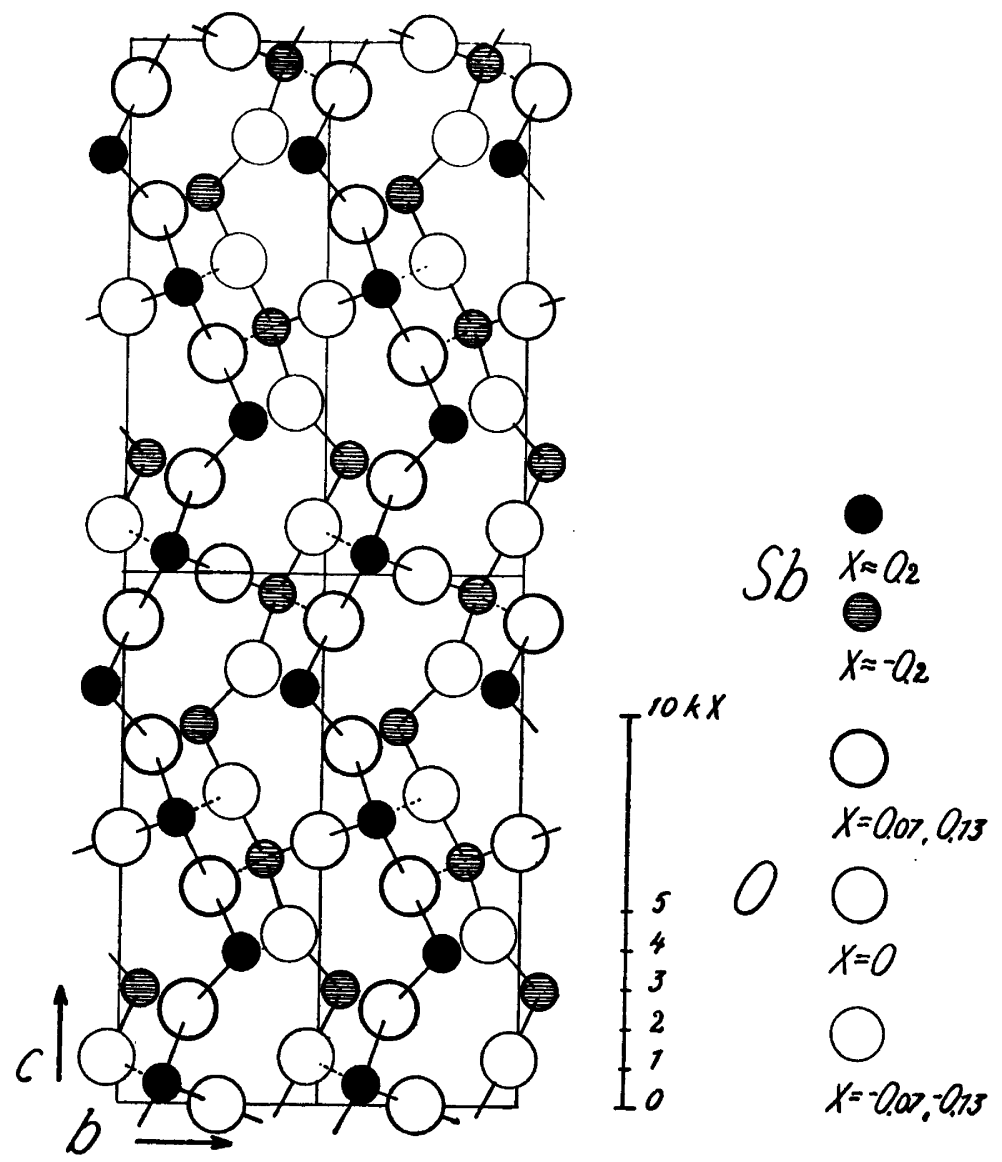

Fig. 5. Orthogonal projection of four adjecent unit cells of $\mathrm{Sb}_{4} \mathrm{O}_{8} \mathrm{Cl}_{2}$ on $x=\mathrm{O}$, shouing the $S b-O$ layer. The $C l$-atoms have been omitted, to make the $S b-O$ chains more obvious.

A combination of $\mathrm{I}$ and III gives quite reasonable $\mathrm{O}-\mathrm{O}$ distan $\mathrm{ces}$. The shortest distance $\mathrm{O}_{\mathrm{I}}-\mathrm{O}_{\mathrm{III}}$ is about $2.5 \mathrm{kX}$ for both positions of $\mathrm{O}_{\mathrm{I}}$. A projection of this configuration is shown in fig. $\mathrm{s} 5$ and 6. (This is for $\mathrm{Sb}_{4} \mathrm{O}_{5} \mathrm{Cl}_{2}$ with the final parameters).

In I + II there will be no oxygen or halogen atoms immediately between $\mathrm{Sb}_{1}$ and $\mathrm{Sb}_{2}$. In I + III, however, there is one oxygen between them. This seems to favour I + III, especially as Sb - O chains will be formed in I + III, which seems fairly plausible, as the antimony atoms do in fact appear to form chains.

To fix the $x$-parameters better, cuts were later on made at $z \approx 2.4 \mathrm{kX}$ and $z \approx-1.2 \mathrm{kX}$, when the other atomic positions had been determined more accurately. This gave the following oxygen positions: 

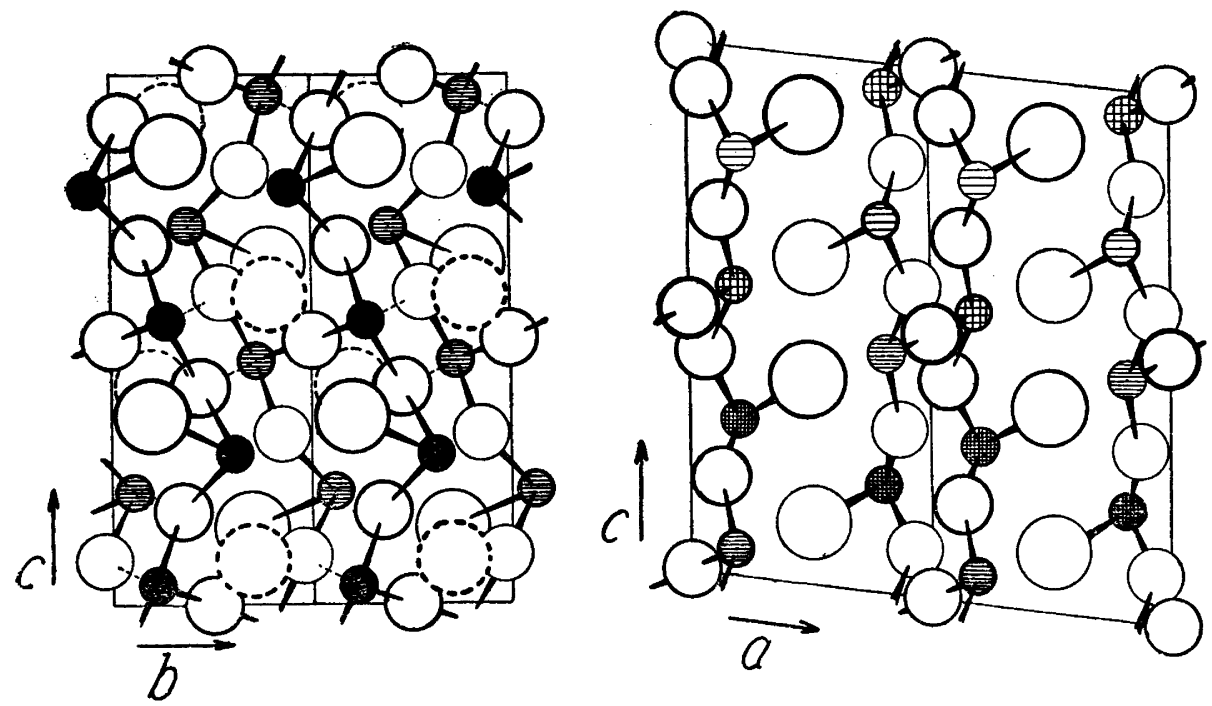

Sb $x=Q_{2} \quad x=-Q_{2}$

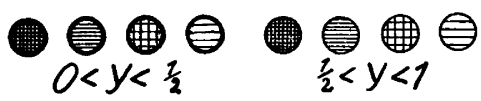

00

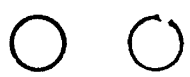

$x=0,07,013 \quad x=0 \quad x=-0,07,-0,3$

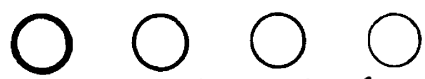

$c l \bigcirc_{x=0.5}$

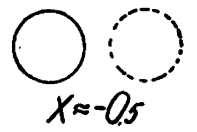

$y=0 \quad 0<y<\frac{1}{2} \quad y=\frac{1}{2} \quad k<y<1$

$$
012345
$$

$\bigcirc$

$0<y<\frac{1}{2} \quad \frac{1}{2}<y<1$

Fig. 6. Orthogonal projections of the structure of $\mathrm{Sb}_{4} \mathrm{O}_{3} \mathrm{Cl}_{2}$ on $x=O(-1 / 2 \lesssim x \lesssim 1 / 2)$ and on the xz-plane.

$\mathrm{Sb}_{4} \mathrm{O}_{5} \mathrm{Br}_{2}: \mathrm{O}_{1} 2$ (c) $\left(00 \frac{1}{2}\right),\left(0 \frac{1}{2} 0\right) \mathrm{O}_{2} 4$ (e) $x=0.13, y=0.37, z=0.187 \mathrm{O}_{3} 4(\theta) x=$ $0.08, y=0.04, z=-0.084$.

and similarly

$\mathrm{Sb}_{4} \mathrm{O}_{5} \mathrm{Cl}_{2}: \mathrm{O}_{1} 2$ (c) $\left(00 \frac{1}{2}\right),\left(0 \frac{1}{2} 0\right) \mathrm{O}_{2} 4$ (e) $x=0.13, y=0.35, z=0.185 \mathrm{O}_{8} 4$ (e) $x=$ $0.07, y=0.05, z=-0.085$.

\section{FURTHER DISCUSSION OF INTENSITIES}

When a more exact intensity calculation was carried out for $h k 0$ of $\mathrm{Sb}_{4} \mathrm{O}_{5} \mathrm{Br}_{2}$, it was found impossible to obtain good agreement for the weak 
reflections $h 10$ as long as it was assumed that $\left|x_{15 b}\right|=\left|x_{2 s b}\right| \cdot$ Assuming them to be unequal, the best agreement was obtained with:

$$
\begin{array}{lll}
\mathrm{Sb}_{1} \text { at } x=0.174, & y=0.225 \\
\mathrm{Sb}_{2} \text { at } x=-0.194, & y=0.125 \\
\mathrm{Br} \text { at } x=0.51, & y=0.705
\end{array}
$$

Table 1 shows that the agreement between observed and calculated intensities for the Weissenberg photograph $h k 0$ is quite good.

Table 1. Calculated and observed intensities of hkO from Weissenberg photograph of $\mathrm{Sb}_{4} \mathrm{O}_{5} \mathrm{Br}_{2}$. CuKa radiation.

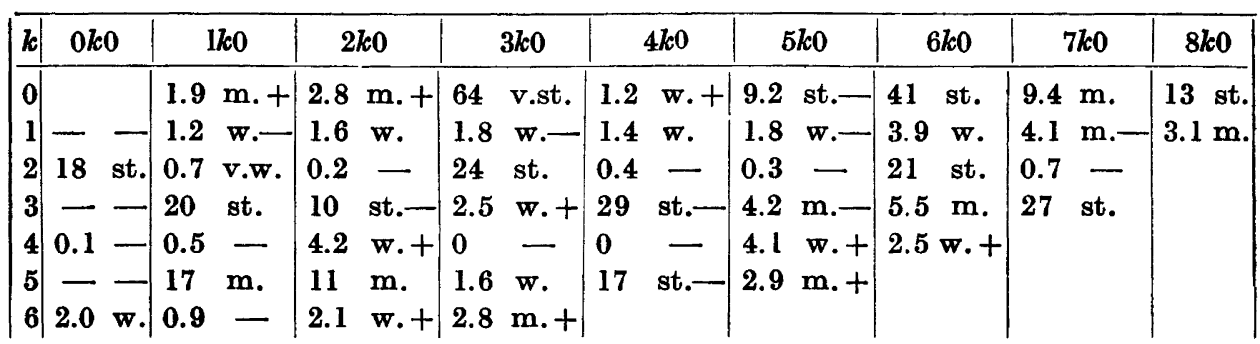

Similarly for $\mathrm{Sb}_{4} \mathrm{O}_{5} \mathrm{Cl}_{2}$ (table 4):

$$
\begin{array}{lll}
\mathrm{Sb}_{1} \text { at } x=0.186, & y=0.225 \\
\mathrm{Sb}_{2} \text { at } x=-0.204, & y=0.113 \\
\mathrm{Cl} \text { at } x=0.51, & y=0.703
\end{array}
$$

Table 2. Calculated and observed intensities of hol from Weissenberg photograph of $\mathrm{Sb}_{4} \mathrm{O}_{5} \mathrm{Br}_{2}$. $\mathrm{CuKa}$ radiation.

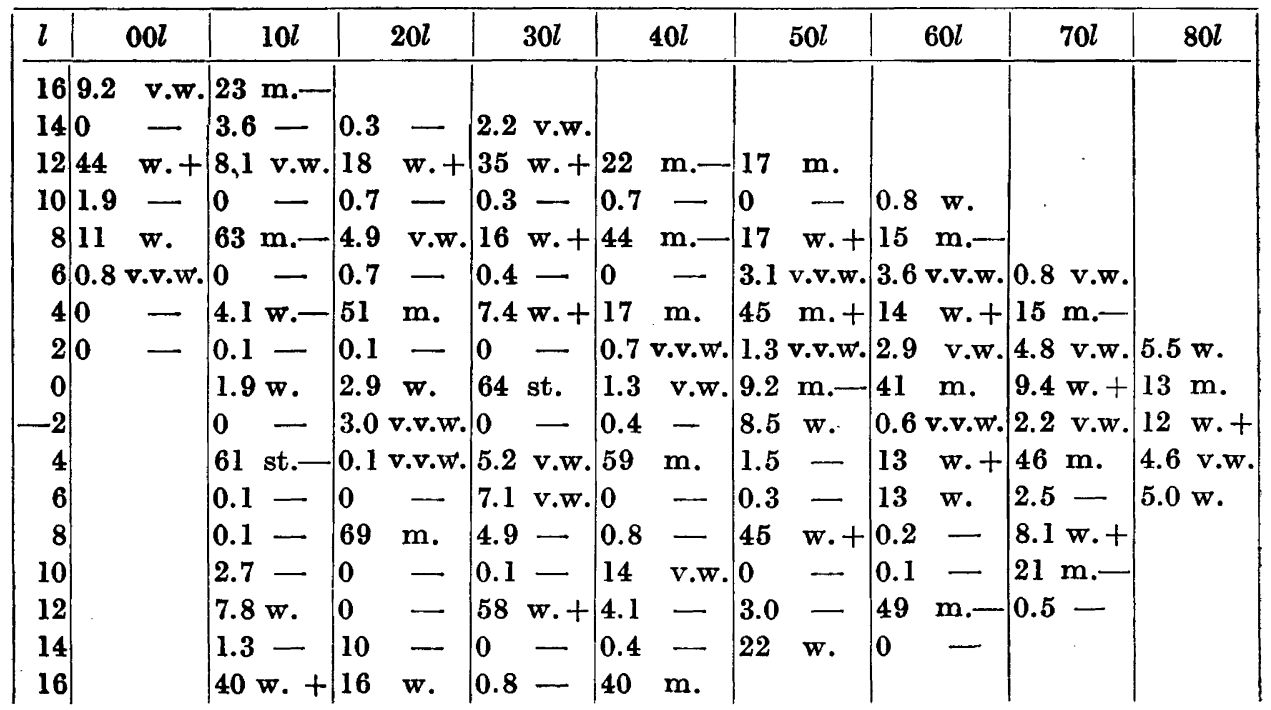


Table 3. Calculated and observed intensities of hll from Weissenberg photograph of $\mathrm{Sb}_{4} \mathrm{O}_{5} \mathrm{Br}_{2}$. $\mathrm{CuKa}$ radiation.

\begin{tabular}{|c|c|c|c|c|c|c|c|c|c|c|c|c|c|c|c|}
\hline$l$ & 011 & & $11 l$ & & $21 l$ & & $31 l$ & & 412 & & 516 & & 612 & $71 l$ & $81 l$ \\
\hline & 0.3 & 0.4 & - & & & & & & & & & & & & \\
\hline 1 & $3.5 \mathrm{w}$ & 2.8 & w. & 1.2 & v.w. & & & & & & & & & & \\
\hline & $13 \mathrm{w}$ & 33 & m.- & 11 & m. & 13 & st. & & & & & & & & \\
\hline 13 & 0.7 v.w & 4.2 & w. & 1.4 & v.v.w. & 2.9 & w. & 1.8 & v.w. & & & & & & \\
\hline 12 & 3.6 v.w & .0 & 一 & 0.7 & 一 & 1.2 & v.w. & 0.1 & v.v.w. & 1.3 & v.w. & & & & \\
\hline 11 & 0 & 3.5 & w. & 3.5 & w. & 1.4 & v.w. & 4.4 & w. + & 1.9 & v.w. & & & & \\
\hline 10 & 2.7 v.w & 8.5 & w. + & 34 & m. + & 13 & m. & 12 & m. + & 23 & st. & 24 & st. & & \\
\hline 9 & 0 & 3.0 & w. & 9.0 & $\mathbf{w .}+$ & $0.1 \mathrm{~V}$ & v.v.w. & 2.1 & w. & 1.8 & v.v.w. & 4.4 & w.t & & \\
\hline 8 & $0.8-$ & 1.6 & v.w. & 0.4 & v.w. & 1.7 & v.w. & .0 & 一 & 1.6 & w. $t$ & 2.6 & w. & & \\
\hline 7 & $8.3 \mathrm{~m}$. & 0 & - & 2.4 & w. & 2.8 & w.- & 2.4 & w. & 3.6 & w.t & 1.1 & v.v.w. & $4.6 \mathrm{~m}$. & \\
\hline 6 & 52 v.st & 0.8 & v.w. & 6.4 & m. & 42 & v.st. & 6.9 & m. & 8.1 & m.t & 25 & st. & 17 st. & \\
\hline 5 & $4.4 \mathrm{~m}$. & 0.3 & v.v.w. & 3.1 & w. + & 5.3 & $\mathbf{m}$. & 1.7 & w. & 5.9 & m. & 2.8 & w. & $4.5 \mathrm{w.}+$ & \\
\hline 4 & 0 & 0.4 & v.v.w. & 0 & - & 0.6 & w. & 0.8 & w. & 0.4 & - & 3.0 & w. + & -2.3 w. + & \\
\hline 3 & $1.2 \mathrm{~m}$. & 6.2 & m. & 0.1 & - & 2.6 & $\mathrm{~m}$. & 3.6 & m. & 2.0 & w. & 2.1 & w. + & 0.9 w. & \\
\hline 2 & $1.6 \mathrm{~m}$ & 52 & v.st. & 0.8 & w. & 5.8 & st. & 44 & v.st. & 5.5 & w. $t$ & 9.4 & m.- & -31 st. & 11 st. \\
\hline 1 & & 8.8 & st. & 0.2 & v.v.w. & 2.2 & $\mathrm{~m}$. & 5.8 & m. & 0.4 & w. & 3.0 & w.t & $0.6 \mathrm{w}$. & $6.9 \mathrm{m.}+$ \\
\hline 0 & & 1.0 & m. & 1.4 & m.- & 1.6 & $\mathrm{~m}$. & 1.5 & w. & 1.9 & $\mathbf{w}$. & 4.1 & w. & $4.1 \mathrm{~m}$. & $3.0 \mathrm{~m} . t$ \\
\hline 1 & & 1.4 & w. & 8.3 & m. - & -0 & - & 1.2 & w. & 2.3 & $\mathbf{w}$. & 3.2 & w.t & $2.6 \mathrm{w} . t$ & 1.2 \\
\hline 2 & & 0.4 & - & 51 & st. & 0 & - & 3.1 & m. & 40 & v.st. & 2.7 & w. & $6.4 \mathrm{~m} .-$ & 24 st. \\
\hline 3 & & 0.6 & v.w & 5.5 & m.- & 0.1 & - & 6.6 & m.- & 7.6 & w. + & 0.4 & 一 & $7.1 \mathrm{~m} .-$ & 2.6 v.v.w \\
\hline 4 & & 1.0 & v.v.w & 0.9 & w. & 0.3 & v.v.w. & 3.5 & w. & 2.6 & w. & 1.6 & w. & $7.1 \mathrm{~m}$. & $7.2 \mathrm{~m}$. \\
\hline 5 & & 0 & - & 1.5 & w. & 6.6 & $\mathrm{~m}$. & 0.4 & 一 & 1.8 & w. & 2.7 & w. & $2.9 \mathrm{w}$. & 1.4 w. \\
\hline 6 & & 2.8 & m. - & 0.2 & - & 51 & st.- & 0.2 & - & 3.1 & w. & 41 & st. & 0.5 一 & $5.5 \mathrm{~m}$. \\
\hline 7 & & 2.7 & w. & 0.6 & v.w. & 6.1 & m. & -0.2 & - & 3.6 & w. & 3.5 & w. & $0.9-$ & $6.7 \mathrm{~m}$. \\
\hline 8 & & 0.3 & 一 & 6.7 & w. & 0.5 & - & 0.4 & - & 12 & w. & 1.4 & v.w. & $1.2 \mathrm{w}$ & \\
\hline 9 & & 7.9 & w. & 0.4 & - & 0.4 & - & 5.5 & v.w. & 0.4 & - & 0.8 & w. & $1.4 \mathrm{w}$. & \\
\hline 10 & & 42 & m. & 3.8 & w. & 0 & - & 41 & w. + & 0.7 & - & 2.3 & w. & 32 st. & \\
\hline 11 & & 6.6 & w.- & 1.9 & w.- & 2.0 & v.v.w. & 7.2 & w. - & -0.1 & - & 7.4 & w.t & $7.2 \mathrm{m.}+$ & \\
\hline 12 & & 0.6 & 一 & 0 & - & 8.8 & w. - & -1.1 & - & 0.3 & - & 17 & m. & & \\
\hline 13 & & 0 & 一 & 5.5 & w.- & -0.1 & - & 2.1 & - & 7.2 & w. & 0.4 & - & & \\
\hline 14 & & 3.5 & v.w & 37 & w. + & -7.7 & w.- & -0 & 一 & & st.- & & & & \\
\hline 15 & & 0.2 & - & 7.4 & w. & 3.5 & w.- & -1.2 & - & & & & & & \\
\hline 16 & & 10 & w. & 0 & -. & & & & & & & & & & \\
\hline
\end{tabular}

As the $x$-parameters now seemed to be fixed satisfactorily, the $z$-parameters were determined more accurately from the $h 0 l$ reflections in the Weissenberg photographs. It proved, however, rather difficult to obtain very satisfactory agreement. The reflections $00 l$ with $l=2+4 \mathrm{n}$, which are weak, could not be explained as depending entirely on oxygen. Therefore, $z_{1 \mathrm{Sb}}+z_{2 \mathrm{sb}}$ could not be exactly 0.25 and $z_{\text {hal. }}$ could hardly be exactly $\frac{1}{8}$. However, small variations of $z_{1 \mathrm{sb}}$ around 0.05 and $\mathrm{z}_{2 \mathrm{Sb}}$ around 0.20 do not influence the $00 \mathrm{l}$ reflections very much. 
The intensities were calculated for different $z_{\text {hal }}$, and it seemed probable that $z_{\text {hal }}<\frac{1}{8}$. Finally the parameters of the oxybromide giving the best calculated intensities were chosen as $z_{1 \mathrm{sb}}=0.051, z_{2 \mathrm{sb}}=0.203$ and $z_{\mathrm{Br}}=0.118$.

The calculated and observed intensities of $h 0 l$ from the Weissenberg photograph of the oxybromide are given in table 2. Considering the general weakening of all reflections in the vicinity of $00 l$ the agreement is good.

The calculated and observed intensities of $h 1 l$ of the oxybromide are given in table 3. Here the agreement seems to be very satisfactory.

Table 4. Intensities of hko from Weissenberg photograph of $\mathrm{Sb}_{4} \mathrm{O}_{5} \mathrm{Cl}_{2}$. CuKa radiation. The calculated intensity is given on the left of each column, and the intensity estimated for Patterson analysis on the right.

\begin{tabular}{|c|c|c|c|c|c|c|c|c|c|c|c|c|c|c|c|c|}
\hline $\boldsymbol{k}$ & \multicolumn{2}{|c|}{$0 k 0$} & \multicolumn{2}{|c|}{$1 k 0$} & \multicolumn{2}{|c|}{$2 k 0$} & \multicolumn{2}{|c|}{$3 k 0$} & \multicolumn{2}{|c|}{$4 k 0$} & \multicolumn{2}{|c|}{$5 k 0$} & \multicolumn{2}{|c|}{$6 k 0$} & \multicolumn{2}{|c|}{$7 k 0$} \\
\hline 0 & & & 4.6 & 50 & & & 38 & 90 & 3.0 & 8 & 24 & 50 & 13 & 17 & & 50 \\
\hline 1 & - & - & 1.8 & 17 & 2.1 & 3 & 0.4 & - & 1.8 & 3 & 2.2 & 3 & 0.2 & 一 & 5.3 & 17 \\
\hline 2 & 8.1 & 100 & 0 & - & 1.9 & 17 & 12 & 50 & 0 & - & 2.2 & 8 & 8.5 & 22 & 1.1 & 5 \\
\hline $\mathbf{3}$ & 一 & - & 25 & 100 & 9.8 & 50 & 8.8 & 30 & 33 & 60 & 0.6 & 3 & 19 & 50 & 17 & 60 \\
\hline 4 & 0 & - & 0 & - & 1.7 & 6 & 0 & - & 0.4 & 3 & 0.6 & 3 & 3.2 & 15 & & \\
\hline 5 & - & - & 10 & 45 & 5.0 & 25 & 2.3 & 20 & 10 & 50 & 0.2 & 15 & & & & \\
\hline 6 & 7.9 & 22 & 1.3 & 1 & 7.6 & 30 & 6.4 & 40 & & & & & & & & \\
\hline
\end{tabular}

Table 5. Intensities of hOl from Weissenberg photograph of $\mathrm{Sb}_{4} \mathrm{O}_{5} \mathrm{Cl}_{2}$. CuKa radiation. The calculated intensity is given on the left of each column, and the intensity estimated for Patterson analysis on the right.

\begin{tabular}{|c|c|c|c|c|c|c|c|c|c|c|c|c|c|c|c|c|}
\hline$l$ & \multicolumn{2}{|c|}{$00 l$} & \multicolumn{2}{|c|}{$10 l$} & \multicolumn{2}{|c|}{$20 l$} & \multicolumn{2}{|c|}{$30 l$} & \multicolumn{2}{|c|}{$40 l$} & \multicolumn{2}{|c|}{$50 l$} & \multicolumn{2}{|c|}{$60 l$} & \multicolumn{2}{|c|}{$70 l$} \\
\hline 16 & 1.8 & 6 & 35 & 80 & 18 & 40 & & & & & & & & & & \\
\hline 14 & 0 & - & 1.0 & 2 & 0 & - & 2.9 & 7 & 0 & - & & & & & & \\
\hline 12 & 33 & 90 & 3.0 & 12 & 31 & 80 & 17 & 25 & 20 & 50 & 24 & 50 & & & & \\
\hline 10 & 1.0 & 5 & 0 & - & 0.3 & - & 0 & - & 1.1 & 3 & 0 & - & & & & \\
\hline 8 & 18 & 95 & 45 & 100 & 2.4 & 7 & 29 & 50 & 18 & 25 & 21 & 40 & 23 & 50 & & \\
\hline 6 & 0.2 & 5 & 0 & - & 0.9 & 一 & 0.5 & - & 0.1 & - & 3.5 & 5 & 1.0 & - & 1.6 & 7 \\
\hline 4 & 1.7 & 40 & 12 & 15 & 31 & 60 & 6.7 & 25 & 32 & 95 & 17 & 40 & 22 & 40 & 21 & 50 \\
\hline 2 & 0 & - & 0.1 & - & 0.2 & - & 0.1 & 3 & 0.1 & 2 & 2.1 & 5 & 4.2 & 7 & 0.7 & - \\
\hline 0 & & & 4.6 & 50 & 12 & 60 & 38 & 90 & 3.0 & 8 & 24 & 50 & 13 & 17 & 21 & 40 \\
\hline-2 & & & 0.1 & - & 1.8 & 2 & 0 & 一 & 1.0 & 3 & $\mathbf{3 . 4}$ & 4 & 1.2 & 5 & 3.3 & 7 \\
\hline 4 & & & 45 & 40 & 0.4 & - & 20 & 15 & 35 & 40 & 5.0 & 4 & 31 & 45 & 14 & 17 \\
\hline 6 & & & 0.1 & - & 0.1 & - & 2.9 & - & 0.2 & - & 1.4 & - & 3.6 & 3 & 5.3 & 6 \\
\hline 8 & & & 2.6 & 10 & 53 & 22 & 3.6 & - & 12 & 6 & 26 & 15 & 4.6 & 6 & 27 & 40 \\
\hline 10 & & & 0.8 & - & 0 & - & 0.2 & - & 6.7 & 3 & 0.1 & - & 1.6 & 1 & 5.8 & 17 \\
\hline 12 & & & 11 & 40 & 5.9 & 13 & 48 & 50 & 1.5 & 5 & 21 & 20 & 30 & 40 & & \\
\hline 14 & & & 0.2 & 5 & 4.4 & 5 & 0 & - & 0.3 & - & 9.6 & 15 & & & & \\
\hline 16 & & & 36 & 80 & 18 & 50 & 3.5 & 15 & & & & & & & & \\
\hline
\end{tabular}


Variations for the oxychloride gave $z_{1 \mathrm{Sb}}=0,049, z_{2 \mathrm{Sb}}=0.203$ and $z_{\mathrm{cl}}=$ 0.115 as the most probable values. The calculated and observed intensities of $h 0 l$ from the Weissenberg photograph are given in table 5. There appeared at first to be a certain disagreement between the observed and calculated intensities of 004 and 104. $I(004)_{\text {calc. }} \sim 1.7$ and $I(104)_{\text {calc. }} \sim 12$, whereas $I(004)_{\text {obs. }}$ is definitely stronger than $I(104)_{\text {obs. }}$ in the Weissenberg photograph. This could not be overcome by small variations of the parameters since the indices were low. From the powder photograph (table 8), it was, however found that $I(004)$ must be lower than $I(104)$, in spite of the fact that their $\sin ^{2} \Theta$ coincide with others. There seems to be a general enhancement of the observed intensities of $00 l$, and a general weakening in other parts, especially in the neighbourhood of the zone n0 $\overline{4 n}$ in the Weissenberg photograph. Taking these facts into consideration, the agreement between calculated and observed intensities is fairly satisfactory.

The $0 k l$ intensities of the chloride were then calculated. Table 6 shows that the agreement between calculated and observed intensities is quite good.

Table 6. Intensities of Okl from Weissenberg photograph of $\mathrm{Sb}_{4} \mathrm{O}_{5} \mathrm{Cl}_{2}$. CuKa radiation. The calculated intensity is given on the left of each column, and the intensity estimated for Patterson analysis on the right.

\begin{tabular}{|r|cc|cc|cc|cc|cc|cc|cc|}
\hline$l$ & \multicolumn{2}{|c|}{$00 l$} & \multicolumn{2}{|c|}{$01 l$} & \multicolumn{2}{c|}{$02 l$} & \multicolumn{2}{|c|}{$03 l$} & \multicolumn{2}{c|}{$04 l$} & \multicolumn{2}{|c|}{$05 l$} & \multicolumn{2}{|c|}{$06 l$} \\
\hline 0 & & & - & - & 8.3 & 40 & - & - & 0 & - & - & - & 7.9 & 20 \\
1 & - & - & 1.0 & 15 & 9.8 & 90 & 1.4 & 14 & 0 & - & 0.2 & 9 & 1.9 & 18 \\
2 & 0 & - & 4.8 & 15 & 6.2 & 90 & 0 & 2 & 25 & 115 & 0 & - & 0.1 & 3 \\
3 & - & - & 1.9 & 6 & 0.7 & 4 & 0.2 & 1 & 9.6 & 65 & 16 & 85 & 18 & 110 \\
4 & 1.7 & 50 & 0.1 & - & 0 & 1 & 29 & 115 & 0.2 & 3 & 11 & 85 & 1.3 & 4 \\
5 & - & - & 3.4 & 6 & 1.2 & 4 & 5.5 & 60 & 2.6 & 14 & 4.8 & 40 & 3.1 & 40 \\
6 & 0.2 & 6 & 36 & 40 & 1.0 & 3 & 0.2 & 3 & 2.4 & 14 & 0.7 & - & 0.3 & - \\
7 & - & - & 8.4 & 40 & 2.8 & 6 & 4.4 & 14 & 0 & 3 & 0.8 & 2 & & \\
8 & 18 & 120 & 1.1 & 3 & 2.3 & 5 & 13 & 60 & 0.5 & 3 & 6.4 & 40 & & \\
9 & - & - & 0.2 & - & 3.6 & 14 & 0.8 & 7 & 2.5 & 14 & 20 & 80 & & \\
10 & 1.0 & 6 & 0 & - & 11 & 40 & 0.8 & 1 & 28 & 90 & 0 & 1 & & \\
11 & - & - & 0 & - & 11 & 40 & 1.9 & 7 & 0.5 & 2 & 6.6 & 80 & & \\
12 & 33 & 115 & 1.4 & 4 & 9.0 & 40 & 8.8 & 40 & 0.2 & 6 & & & & \\
13 & - & - & 2.0 & 12 & 11 & 30 & 1.3 & 13 & 0.4 & 6 & & & & \\
14 & 0 & - & 18 & 80 & 5.0 & 12 & 0 & - & & & & & & \\
15 & - & - & 4.5 & 12 & 0.2 & 6 & 2.8 & 13 & & & & & & \\
16 & 1.8 & 7 & 0.2 & - & 1.2 & 6 & & & & & &
\end{tabular}

Tables 7 and 8 give the observed and calculated $\sin ^{2} \Theta$ and intensities of the powder photographs of $\mathrm{Sb}_{4} \mathrm{O}_{5} \mathrm{Cl}_{2}$ and $\mathrm{Sb}_{4} \mathrm{O}_{5} \mathrm{Br}_{2}$. 
Table 7. Powder photographs of $\mathrm{Sb}_{4} \mathrm{O}_{5} \mathrm{Br}_{2}$. CrKa radiation.

\begin{tabular}{|c|c|c|c|c|c|c|c|c|c|}
\hline$h k l$ & $\begin{array}{l}\sin ^{2} \theta \\
\text { calc. }\end{array}$ & $\begin{array}{l}\sin ^{2} \theta \\
\text { obs. }\end{array}$ & $\begin{array}{c}I \\
\text { calc. }\end{array}$ & $\begin{array}{c}I \\
\text { obs. }\end{array}$ & $h k l$ & $\begin{array}{c}\sin ^{2} \Theta \\
\text { calc. }\end{array}$ & $\begin{array}{c}\sin ^{2} \theta \\
\text { obs. }\end{array}$ & $\begin{array}{c}I \\
\text { calc. }\end{array}$ & $\begin{array}{c}I \\
\text { obs. }\end{array}$ \\
\hline $\begin{array}{l}012 \\
110\end{array}$ & $\left.\begin{array}{r}0.0791 \\
.0803\end{array}\right\}$ & 0.0790 & $\left\{\begin{array}{l}3.0 \\
2.4\end{array}\right.$ & v.v.w. & $\begin{array}{l}12 \overline{\mathbf{3}} \\
115\end{array}$ & $\left.\begin{array}{l}.2837 \\
.2858\end{array}\right\}$ & $(.2856)$ & $\left\{\begin{array}{c}39 \\
0.8\end{array}\right.$ & $(w .+)$ \\
\hline $11 \overline{1}$ & .0836 & .0833 & 3.2 & v.v.w. & 123 & .3082 & \multirow[t]{2}{*}{.3097} & 6.7 & \multirow[t]{2}{*}{ v.w. } \\
\hline 111 & .0917 & .0916 & 19 & $\mathbf{m}-$ & $21 \overline{5}$ & .3163 & & 3.4 & \\
\hline $11 \overline{2}$ & .1016 & 一 & 0.5 & 一 & 016 & .3163 & \multirow[t]{2}{*}{ ( .3166) } & 105 & \multirow[t]{2}{*}{ (st. - ) } \\
\hline 013 & .1159 & - & 2.2 & - & 024 & $.3172 J$ & & 1.3 & \\
\hline 004 & $.1178\}$ & \multirow{2}{*}{.1181} & 0 & \multirow[b]{2}{*}{ st. } & $31 \overline{1}$ & $.3201)$ & \multirow{6}{*}{.3216} & \multirow{2}{*}{$\left(\begin{array}{l}0 \\
82\end{array}\right.$} & \multirow{6}{*}{ w. } \\
\hline 112 & $.1179\}$ & & 106 & & $22 \overline{1}$ & .3203 & & & \\
\hline 200 & .1224 & .1226 & 2.9 & v.v.w. & 220 & .3211 & & 0.3 & \\
\hline $10 \overline{4}$ & .1321 & $(.1321)$ & 61 & (st.) & 106 & .3217 & & 0 & \\
\hline $11 \overline{3}$ & .1343 & - & 1.1 & - & $11 \overline{6}$ & .3223 & & 5.6 & \\
\hline $20 \overline{2}$ & .1355 & - & 3.0 & - & 214 & .3232 & & 0 & \\
\hline 113 & .1588 & .1588 & 12 & v.w. & 310 & .3250 & ( . .3268) & 3.5 & (v.w.) \\
\hline 104 & .1647 & (.1647) & 4.0 & (v.w.) & 302 & .3295 & - & 0 & - \\
\hline 014 & .1675 & - & 0 & - & $31 \overline{2}$ & .3301 & - & 0 & - \\
\hline 202 & .1681 & - & 0.2 & - & $12 \overline{4}$ & .3314 & .3320 & 44 & m. \\
\hline $21 \overline{1}$ & $.1713\}$ & \multirow{2}{*}{$(.1711)$} & \multirow{2}{*}{$\begin{array}{c}18 \\
3.2\end{array}$} & \multirow{2}{*}{$(w .+)$} & $22 \overline{2}$ & .3343 & - & 0.5 & - \\
\hline 210 & $.1721\}$ & & & & 221 & .3366 ) & \multirow{2}{*}{.3381} & $\int 4.6$ & \multirow{2}{*}{ v.w. } \\
\hline $11 \overline{4}$ & $.1818^{\prime}$ & - & 1.6 & - & $20 \overline{6}$ & $.3399\}$ & & $\{0$ & \\
\hline $21 \overline{2}$ & .1852 & .1850 & 101 & st.- & 311 & .3446 & \multirow[b]{2}{*}{.3452} & 4.2 & \multirow[b]{2}{*}{ w. } \\
\hline 211 & .1876 & - & 0.6 & - & $30 \overline{4}$ & $.3447\}$ & & 5.2 & \\
\hline 020 & .1987 & .1987 & 18 & w. - & $31 \overline{3}$ & $.3548^{\prime}$ & - & 0.5 & - \\
\hline 021 & .2061 & .2054 & 26 & w. & $22 \overline{3}$ & .3632 & - & 0.5 & - \\
\hline $20 \overline{4}$ & .2076 & - & 0.1 & - & 124 & .3641 & - & 0.7 & - \\
\hline $21 \overline{3}$ & .2139 & & $\{10$ & & 222 & .3670 & .3682 & 24 & w.t \\
\hline 114 & $.2148\}$ & $(.2139)$ & $\left\{\begin{array}{l}0.6 \\
0\end{array}\right.$ & (v.w.) & 116 & .3714 & - & 1.8 & - \\
\hline 212 & $.2178^{\prime}$ & - & 1.9 & - & 312 & .3791 & .3807 & 12 & w. \\
\hline 022 & $.2282)$ & & / 9.3 & & 025 & .3838 & - & 1.1 & - \\
\hline 120 & $.2293\}$ & ( .2278) & 1.5 & $(\mathrm{~m} .-$ ) & $21 \overline{6}$ & .3895 & - & 0.5 & - \\
\hline $12 \overline{1}$ & .2326 & & 10 & & $12 \overline{5}$ & $3940)$ & & 39 & \\
\hline 015 & .2338 & ( . .2339) & 7.4 & (v.v.w.) & $31 \overline{4}$ & $.3944\}$ & ( .3944) & $\{0.5$ & $(\mathrm{w} .+)$ \\
\hline & & & & & 215 & $.3981^{\prime}$ & - & 6.7 & - \\
\hline 121 & .2408 & 一 & 0 & - & $22 \overline{4}$ & .4068 & - & 0.2 & - \\
\hline $11 \overline{5}$ & .2449 & - & 0 & - & 223 & .4122 ) & & (34 & \\
\hline $12 \overline{2}$ & .2507 & .2514 & 9.5 & v.w. & 017 & $.4125\}$ & $(4129)$ & $\{17$ & (m. 一) \\
\hline $21 \overline{4}$ & .2578 & $(.2579)$ & 1.7 & (v.v.w.) & $11 \overline{7}$ & .4145 & & 5.8 & \\
\hline 213 & .2632 & $(.2628)$ & 0.2 & (w.) & 313 & .4284 & $(.4292)$ & 4.4 & (w.) \\
\hline 023 & .2654 ) & & 0.2 & & 125 & .4349 & - & 8.7 & 一 \\
\hline 006 & .2665 & $(.2671)$ & 0.8 & (v.w.) & 206 & .4380 & $(.4396)$ & 0.8 & (v.w.) \\
\hline 122 & ال2671. & & 2.3 & & 304 & .4429 & $(.4441)$ & 7.4 & (v.w.) \\
\hline $10 \overline{6}$ & .2726 & 一 & 0.1 & - & $31 \overline{5}$ & .4487 & $(.4486)$ & 13 & (w.) \\
\hline 204 & $.2736 \mid$ & & $\int 50$ & & 031 & .4545 & - & 1.2 & - \\
\hline 300 & $.2753\}$ & $.2760)$ & $\{64$ & (st.) & $22 \overline{5}$ & .4653 & - & 2.7 & - \\
\hline $30 \overline{2}$ & $.2804^{\prime}$ & - & 0 & - & 026 & .4653 & - & 3.4 & - \\
\hline
\end{tabular}




\begin{tabular}{|c|c|c|c|c|c|c|c|c|c|}
\hline$h k l$ & $\begin{array}{c}\sin ^{2} \Theta \\
\text { calc. }\end{array}$ & $\begin{array}{c}\sin ^{2} \Theta \\
\text { obs. }\end{array}$ & $\begin{array}{c}I \\
\text { calc. }\end{array}$ & $\begin{array}{c}I \\
\text { obs. }\end{array}$ & $h k l$ & $\begin{array}{c}\sin ^{2} \Theta \\
\text { calc. }\end{array}$ & $\begin{array}{c}\sin ^{2} \Theta \\
\text { obs. }\end{array}$ & $\begin{array}{c}I \\
\text { calc. }\end{array}$ & $\begin{array}{c}I \\
\text { obs. }\end{array}$ \\
\hline $30 \overline{6}$ & .4683 ) & & 7.1 & & $23 \overline{1}$ & $.5680\}$ & & $\int 26$ & \\
\hline $32 \overline{1}$ & $.4691\}$ & $(.4694)$ & $\{27$ & (w.) & 230 & $.5689\}$ & .5688 & $\{20$ & w. \\
\hline $12 \overline{6}$ & .4713) & & 15 & & 315 & .5720 & - & 10 & - \\
\hline 117 & .4717 & - & 0 & - & 323 & .5778 ) & & $(1.9$ & \\
\hline $10 \overline{8}$ & .4718 & - & 0.1 & 一 & $13 \overline{4}$ & .5786 & $(.5789)$ & 2.2 & (v.v.w.) \\
\hline 224 & $.4723)$ & & 47 & & $21 \overline{8}$ & .5788 ) & & 613 & \\
\hline $13 \overline{1}$ & .4736 & & 0.1 & & $23 \overline{2}$ & .5819 & - & 7.4 & 一 \\
\hline 008 & .4739 & .4739 & $\{11$ & m. & 231 & .5845 & - & 2.2 & - \\
\hline 320 & .4740 J & & 47 & & 118 & .5860 & - & 3.2 & - \\
\hline 032 & .4767 & 一 & 1.5 & - & 217 & $.5919\}$ & & 4.6 & \\
\hline $21 \overline{7}$ & .4776 & & 1.1 & & $41 \overline{4}$ & $.5919\}$ & .5918 & 6.7 & v.v.w. \\
\hline 130 & .4777 & & 39 & & $32 \overline{5}$ & .5968 & - & 9.2 & 一 \\
\hline $32 \overline{2}$ & .4791 & .4789 & 18 & w. & $31 \overline{7}$ & .6005 & - & 12 & 一 \\
\hline 131 & .4818 J & & 125 & & 412 & .6024 & $(.6030)$ & 88 & $(\mathrm{~m} .-)$ \\
\hline $40 \overline{2}$ & .4863 & - & 0.4 & 一 & $\mathbf{2 3 \overline { 3 }}$ & $.6106\}$ & & $\{31$ & \\
\hline 216 & .4877 & & $\{13$ & & 134 & $.6117\}$ & .6117 & $\{31$ & w. \\
\hline 400 & $.4894\}$ & .4894 & 1.3 & w.- & 232 & $.6149^{\prime}$ & - & 0.5 & - \\
\hline 314 & .4925 & - & 1.2 & 一 & 306 & .6160 & - & 0.4 & - \\
\hline 321 & .4937 & .4944 & 20 & w.- & 127 & .6198 & .6198 & 28 & v.w. \\
\hline $13 \overline{2}$ & .4991 & (.4999) & 4.0 & (w. 一) & $22 \overline{7}$ & .6250 & .6250 & 30 & w. - \\
\hline 323 & .5038 & - & 1.7 & - & 035 & .6310 & .6320 & 26 & v.v.w. \\
\hline 033 & .5137 & - & 0.4 & - & 226 & .6364 & - & 7.9 & - \\
\hline 132 & .5155 & & 8.2 & & $1 \overline{\mathbf{3 5}}$ & .6410 & & ( 1.4 & \\
\hline $31 \overline{6}$ & $.5179\}$ & .5178 & 100 & m. & $11 \overline{9}$ & .6413 & & 16 & \\
\hline 126 & .5204 & 一 & 13 & - & 324 & $.6419\}$ & ( .6423) & 1.5 & (v.w.) \\
\hline $11 \overline{8}$ & .5215 & - & 0.7 & - & $41 \overline{5}$ & .6419 ( & & 0.8 & . \\
\hline 018 & .5236 & - & 1.6 & - & $30 \overline{8}$ & .6493 & 一 & 5.0 & 一 \\
\hline 322 & .5284 & - & 12 & 一 & $\begin{array}{l}234 \\
413\end{array}$ & $\left.\begin{array}{l}.6540 \\
.6559\end{array}\right\}$ & $(.6542)$ & $\left\{\begin{array}{c}45 \\
6.3\end{array}\right.$ & (w.) \\
\hline $20 \overline{8}$ & .5292 & & 69 & & $40 \overline{6}$ & .6570 & 一 & 0 & 一 \\
\hline $41 \overline{1}$ & $.5307\}$ & .5305 & 2.2 & v.w. & 233 & .6601 & - & 0 & 一 \\
\hline $13 \overline{3}$ & .5310 & & 6.7 & & 208 & .6613 & - & 4.9 & $-\bullet$ \\
\hline $41 \overline{2}$ & .5363 & & (6.1 & & 316 & .6656 ) & & 83 & \\
\hline 108 & .5364 & .5357 & $\{61$ & w. & $32 \overline{\mathbf{6}}$ & $.6657\}$ & $(.6662)$ & 3.0 & $(w \cdot+)$ \\
\hline $22 \overline{6}$ & .5373 J & & 10 & & $12 \overline{8}$ & .6687 ) & & 4.1 & \\
\hline 410 & .5398 & - & 2.9 & 一 & 028 & .6711 & 一 & 1.9 & - \\
\hline $40 \overline{4}$ & $.5423\}$ & & $\{58$ & & 404 & .6745 & .6744 & 17 & v.w. \\
\hline $32 \overline{4}$ & $.5427\}$ & $(.5423)$ & 0.4 & $(\mathrm{w} \cdot+)$ & 019 & .6779 & - & 0 & - \\
\hline 225 & .5469 & .5470 & 33 & v.v.w. & $42 \overline{1}$ & .6795 & - & 2.5 & - \\
\hline 402 & .5528 & - & 0.7 & - & 135 & $.6823\}$ & & $\int 4.4$ & \\
\hline 133 & $.5558\}$ & & $\{24$ & & $42 \overline{2}$ & $.6851\}$ & $(.6845)$ & 6.3 & (v.w.) \\
\hline $41 \overline{3}$ & $.5567\}$ & $(.5565)$ & 14 & (v.w.) & 420 & $.6886^{\prime}$ & - & 0.8 & 一 \\
\hline 027 & .5603 & - & 2.3 & 一 & $21 \overline{9}$ & .6961 & - & 0.8 & - \\
\hline $12 \overline{7}$ & .5620 & 一 & 0.2 & 一 & $31 \overline{8}$ & .6989 & ( .6994) & 1.0 & (v.v.w.) \\
\hline 411 & $.5637\}$ & .5641 & $\{12$ & w. & $\mathbf{4 2 \overline { 3 }}$ & $.7055\}$ & & 22 & \\
\hline 034 & $.5645\}$ & .0041 & 49 & w. & $41 \overline{6}$ & .7066 \} & .7053 & 0.4 & v.w. \\
\hline
\end{tabular}


Table 8. Powder photographs of $\mathrm{Sb}_{4} \mathrm{O}_{5} \mathrm{Cl}_{2}$. CrKa radiation.

$\begin{array}{llllllll}\sin ^{2} \Theta & \sin ^{2} \Theta & I & I & \sin ^{2} \Theta & \sin ^{2} \theta & I & I\end{array}$

\begin{tabular}{|c|c|c|c|c|c|c|c|c|c|}
\hline$h k l$ & calc. & obs. & calc. & obs. & $h k l$ & calc. & obs. & calc. & obs. \\
\hline 012 & 0.0790 & $(0.0790)$ & 9.5 & $(\mathrm{~m} .-\mathrm{)}$ & $3 \overline{24}$ & .5771 & 一 & 1.6 & 一 \\
\hline 110 & .0842 & .0838 & 3.5 & v.w. & 118 & .5826 & - & 1.9 & 一 \\
\hline $11 \overline{1}$ & .0874 & $(.0876)$ & 5.8 & (w.) & $13 \overline{4}$ & .5858 & - & 0.1 & - \\
\hline 111 & .0954 & .0954 & 17 & m. + & $23 \overline{1}$ & $.5872)$ & ( .5879) & (14 & (w) \\
\hline $11 \overline{2}$ & .1052 & .1054 & 7 & w. & 230 & $.5879\}$ & $(.0879)$ & 20 & (w.) \\
\hline 013 & $. i 152\}$ & 1157 & 3.9 & & $41 \overline{1}$ & .5891 & 一 & 5.6 & - \\
\hline 004 & $.1158\}$ & .1101 & 1.7 & v.w. & $21 \overline{8}$ & .5894 & 一 & 5.6 & - \\
\hline 112 & .1210 & .1212 & 68 & v.st. & $41 \overline{2}$ & .5950 & .5949 & 24 & m. - \\
\hline $10 \overline{4}$ & .1342 & .1342 & 45 & st. & 410 & .5978 & - & 3.7 & - \\
\hline 200 & $.1366)$ & $(1366)$ & $\int 12$ & & 217 & .6000 & & 7 & \\
\hline $11 \overline{3}$ & $.1374\}$ & $(.1366)$ & $\left\{\begin{array}{r}2.6 \\
\text {. }\end{array}\right.$ & (st.) & $40 \overline{4}$ & .6003 & & 35 & $(m-1)$ \\
\hline $20 \overline{2}$ & .1498 & .1502 & 1.9 & v.v.w. & 315 & .6003 & $(.6008)$ & 8.2 & (m.-) \\
\hline 113 & .1612 & .1612 & 11 & w. & 232 & .6010 J & & 0.8 & \\
\hline 104 & .1658 & & $\int 12$ & (m) & 231 & .6032 & 一 & 1.8 & - \\
\hline 014 & .1659\} & $(.1658)$ & 0.2 & (m.) & 402 & .6088 & - & 0.1 & - \\
\hline 202 & .1814 & .1813 & 0.2 & v.v.w. & 323 & .6101 & 一 & 3.4 & - \\
\hline $11 \overline{4}$ & .1842 & 一 & 0.2 & - & $41 \overline{3}$ & .6154 & .6152 & 20 & w. \\
\hline $21 \overrightarrow{1}$ & .1860 & & $\int 14$ & $m$ & 134 & .6178 & & 33 & \\
\hline 210 & $.1866\}$ & .1861 & 4.4 & m. & 127 & $.6197\}$ & .6198 & $\{20$ & w. \\
\hline $21 \overline{2}$ & .1998 ) & & f 65 & & 411 & .6211 . & & 6.7 & \\
\hline 020 & $.2001\}$ & .2001 & $\{8.1$ & st. & $23 \overline{3}$ & $.6295)^{\circ}$ & & (13 & \\
\hline 211 & .2018 & - & 0.4 & - & $32 \overline{5}$ & .6307 & & 16 & \\
\hline 021 & .2073 & .2075 & 20 & w. & $31 \overline{7}$ & $.6312\}$ & .6319 & 11 & $w-$ \\
\hline 114 & .2158 & - & 0.7 & - & 232 & .6330 & & 0 & \\
\hline $20 \overline{4}$ & .2208 & - & 0.4 & - & 035 & $.6331)$ & & 11 & \\
\hline $21 \overline{3}$ & $.2281)$ & & 9.3 & & $22 \overline{7}$ & .6384 ) & & $f^{22}$ & \\
\hline 022 & .2290 & & 12 & & $11 \overline{9}$ & $.6385\}$ & .6387 & $\{15$ & v.w. \\
\hline 015 & .2310 & .2290 & 7.0 & w. & 019 & .6403 & - & 0.3 & - \\
\hline 212 & .2314 J & & 0.6 & & 306 & .6424 & 一 & 0.5 & - \\
\hline 321 & .5278 & $(.5274)$ & 11 & (v.v.w.) & 226 & .6476 & - & 7.7 & - \\
\hline 108 & .5325 & .5322 & 45 & v.v.w. & $13 \overline{5}$ & .6493 & - & 3.5 & - \\
\hline $32 \overrightarrow{3}$ & $.5381)$ & & 6.5 & & $41 \overline{4}$ & .6504 & 一 & 0.6 & - \\
\hline $13 \overline{3}$ & .5388 & .5394 & 10 & w. & 412 & .6589 & .6590 & 44 & m. \\
\hline $20 \overline{8}$ & .5393 & & 153 & & 028 & .6667 & - & 4.8 & 一 \\
\hline $4 \overline{2}$ & .5449 & - & 1 & 一 & 208 & .6672 & - & 2.4 & - \\
\hline 400 & .5477 & & f 3.0 & & $12 \overline{8}$ & .6690 & - & 0.1 & - \\
\hline $31 \overline{6}$ & $.5485\}$ & $(.5481)$ & 67 & $(\mathrm{w},+)$ & $41 \overline{5}$ & .6700 & - & 1.4 & - \\
\hline $22 \overline{6}$ & .5517 & - & 15 & - & $23 \overline{4}$ & $.6725)$ & & $\{56$ & $\mathbf{w}$ \\
\hline 027 & .5574 & - & 5.8 & 一 & 324 & $.6731\}$ & .6720 & 0.2 & w. \\
\hline 225 & .5595 & $(.5593)$ & 22 & (v.w.) & 233 & .6774 & - & 0.7 & - \\
\hline 322 & .5616 & - & 9.8 & - & $30 \overline{8}$ & .6784 & - & 3.7 & - \\
\hline 133 & .5628 & - & 11 & - & 135 & .6853 & - & 3 & - \\
\hline $12 \overline{7}$ & .5637 & - & 2 & - & 316 & .6925 & .6918 & 43 & m. \\
\hline 034 & .5675 & .5675 & 58 & v.w. & $32 \overline{6}$ & .6988 & - & 0.1 & - \\
\hline
\end{tabular}




\begin{tabular}{|c|c|c|c|c|c|c|c|c|c|}
\hline$h k l$ & $\begin{array}{c}\sin ^{2} \Theta \\
\text { calc. }\end{array}$ & $\begin{array}{c}\sin ^{2} \Theta \\
\text { obs. }\end{array}$ & $\begin{array}{c}I \\
\text { calc. }\end{array}$ & $\begin{array}{c}I \\
\text { obs. }\end{array}$ & $h k l$ & $\begin{array}{c}\sin ^{2} \Theta \\
\text { calc. }\end{array}$ & $\begin{array}{c}\sin ^{2} \Theta \\
\text { obs. }\end{array}$ & $\begin{array}{c}I \\
\text { calc. }\end{array}$ & $\begin{array}{c}I \\
\text { obs. }\end{array}$ \\
\hline $1 \overline{9}$ & .7052 & 一 & 1 & - & $10 \overline{10}$ & .7228 & 一 & 0.8 & 一 \\
\hline 119 & $.7105)$ & & $\int 9.3$ & & $13 \overline{6}$ & .7235 & - & 0 & 一 \\
\hline 13 & .7114 & $(.7108)$ & $\{2.9$ & (v.v.w.) & 404 & $.7283)$ & & (32 & \\
\hline 36 & .7132 & - & 0.5 & - & $31 \overrightarrow{8}$ & .7285 & .7285 & 1.8 & w. + \\
\hline & .7140 & - & 0.2 & - & 0010 & .7286 J & & 1 & \\
\hline 10 & .7173 & - & 2 & - & & & & & \\
\hline
\end{tabular}

The intensities were calculated from $I \sim p\left[\frac{F}{4 f_{\mathrm{sb}}}\right]^{2}$ for powder photographs, where $p$ is the number of cooperating planes, and from $I \sim\left[\frac{F}{4 f_{\mathrm{sb}}}\right]^{2}$ for Weissenberg photographs. Due consideration was given to the variation of $\frac{f_{\mathrm{A}}}{f_{\mathrm{Sb}}}$ with $\Theta$, except in the Weissenberg photograph of $h l l$ of the oxybromide, where the average values $\frac{f_{\mathrm{B} I}}{f_{\mathrm{Sb}}}=$ $0.645, \frac{f_{\mathrm{O}}}{f_{\mathrm{Sb}}}=0.1$ were used. In the lists of the powder photographs, the limits between the angular ranges of the three different focusing cameras are marked. Reflections systematically absent are omitted. The $\beta$-reflections have been omitted. If a tabulated reflection coincides with a $\beta$-reflection, the $\sin ^{2} \Theta$ and the intensity of the resulting line are given in brackets. The observed intensities are indicated as follows: vst $=$ very strong, st $=$ strong, $m=$ medium, $w=$ weak, $v w=$ very weak and $\mathrm{vvw}=$ very, very weak.

The atomic coordinates of $\mathrm{Sb}_{4} \mathrm{O}_{5} \mathrm{Cl}_{2}$ and $\mathrm{Sb}_{4} \mathrm{O}_{5} \mathrm{Br}_{2}$ are given in table 9.

Table 9. Atomic coordinates of $\mathrm{Sb}_{4} \mathrm{O}_{5} \mathrm{Cl}_{2}$ and $\mathrm{Sb}_{4} \mathrm{O}_{5} \mathrm{Br}_{2}$.

\begin{tabular}{|c|c|c|c|c|c|c|}
\hline & \multicolumn{3}{|c|}{$\mathrm{Sb}_{4} \mathrm{O}_{5} \mathrm{Cl}_{2}$} & \multicolumn{3}{|c|}{$\mathrm{Sb}_{4} \mathrm{O}_{5} \mathrm{Br}_{2}$} \\
\hline & $x$ & $y$ & $z$ & $x$ & $y$ & $z$ \\
\hline $4 \mathrm{Sb}_{1}$ & $0.186 \pm 0.005$ & $0.225 \pm 0.005$ & $0.049 \pm 0.003$ & $0.174 \pm 0.005$ & $0.225 \pm 0.005$ & $0.051 \pm 0.004$ \\
\hline $4 \mathrm{Sb}_{2}$ & $0.796 \pm 0.005$ & $0.113 \pm 0.005$ & $0.203 \pm 0.003$ & $0.806 \pm 0.005$ & $0.125 \pm 0.005$ & $0.203 \pm 0.004$ \\
\hline $4 \times$ & $0.51 \pm 0.01$ & $0.703 \pm 0.01$ & $0.115 \pm 0.005$ & $0.51 \pm 0.01$ & $0.705 \pm 0.01$ & $0.118 \pm 0.005$ \\
\hline 20 & 0 & $\frac{1}{2}$ & 0 & 0 & $\frac{1}{2}$ & $\mathbf{0}$ \\
\hline & 0 & 0 & $\frac{1}{2}$ & 0 & 0 & $\frac{1}{2}$ \\
\hline & 0.13 & 0.35 & 0.185 & 0.13 & 0.37 & 0.387 \\
\hline & 0.07 & 0.05 & 0.915 & 0.08 & 0.04 & 0.916 \\
\hline
\end{tabular}

\section{DISCUSSION. OF THE STRUCTURE}

Projections of the structure of the oxychloride on the $x z$-plane and on the $y z$-plane are shown in fig. 6. The $y z$-projection is an orthogonal projection of the cell for $-\frac{1}{2} \lesssim x \leqq+\frac{1}{2}$ on $x=0$. It shows that the antimony atoms form zig-zag chains in two layers, with a distance of $2.4 \mathrm{kX}$ between 
the layers. The oxygen atoms enter between these layers, so that $\mathbf{S b}-\mathbf{O}$ chains seem to be formed, which are held together by the oxygen in 2 (c), thus forming an $\mathrm{Sb}-\mathrm{O}$ layer. This is more obvious from fig. 5, where the halogens are omitted. Between these layers, there are layers of halogen. As has been mentioned above, $\mathrm{Sb}_{4} \mathrm{O}_{5} \mathrm{Cl}_{2}$ forms two types of crystals, one of which forms thin plates. In order to check the structure, suitable plates were selected and rotation photographs taken around the three axes. They showed that

Table 10. Interatomic distances in $\mathrm{Sb}_{4} \mathrm{O}_{5} \mathrm{X}_{2} . k X$ units.

Within
chain

$$
\mathrm{Sb}_{4} \mathrm{O}_{5} \mathrm{Cl}_{2}
$$

$\mathrm{Sb}_{4} \mathrm{O}_{5} \mathrm{Br}_{2}$

$$
\begin{array}{ccc}
\mathrm{Sb}_{1}-2 \mathrm{O} & 2.02 & 2.06 \\
\mathrm{Sb}_{2}-2 \mathrm{O} & 2.03 & 2.06 \\
\mathrm{Sb}_{1}-\mathrm{Sb}_{2} & 3.88 & 3.83 \\
\mathrm{O}_{2}-\mathrm{O}_{3} \text { at } & \text { "angle" } & 3.21 \\
\mathrm{O}_{2}-\mathrm{O}_{3} & 3.93 &
\end{array}
$$

$2.03 \quad 2.06$

$1.98 \quad 2.04$

$3.88 \quad 3.87$

3.17

3.98

Between atoms

$$
\begin{array}{cc}
\mathrm{Sb}_{1}-\mathrm{O} & 2.22 \\
\mathrm{Sb}_{2}-\mathrm{O} & 2.44 \\
\mathrm{Sb}_{1}-\mathrm{Sb}_{1} & 3.43 \\
\mathrm{Sb}_{1}-\mathrm{Sb}_{2} & 3.44 \\
\mathrm{Sb}_{2}-\mathrm{Sb}_{2} & 3.71 \\
\mathrm{O}_{2}-\mathrm{O}_{3} & 2.67 \\
\mathrm{O}_{3}-\mathrm{O}_{3} & 2.61
\end{array}
$$

2.25

2.51

3.41

3.42

3.72

2.78

2.65

$\begin{array}{lcccccccc}\mathrm{Sb}_{1}-30(4 \mathrm{O}) & 1.89 & 2.02 & 2.06 & (2.22) & 1.89 & 2.03 & 2.06 & (2.26) \\ \mathrm{Sb}_{1}-3 \mathrm{X} & 3.11 & 3.22 & 3.39 & & 3.30 & 3.35 & 3.51 & \\ \mathrm{Sb}_{2}-2 \mathrm{O}(3 \mathrm{O}) & 2.03 & 2.06 & (2.44) & & 1.98 & 2.04 & (\mathbf{2 . 5 1 )} & \\ \mathrm{Sb}_{2}-\mathrm{X}(3 \mathrm{X}) & 2.91 & (3.33 & 3.62) & & 3.03 & (3.42 & 3.65) & \\ & & & & & & & & \\ \mathrm{O}_{1}-2 \mathrm{Sb} b_{1} & 1.89 & & & & 1.89 & & & \\ \mathrm{O}_{2}-2 \mathrm{Sb}(3 \mathrm{Sb}) & 2.02 & 2.03 & (2.44) & & 2.03 & 1.98 & (2.51) & \\ \mathrm{O}_{3}-2 \mathrm{Sb}(3 \mathrm{Sb}) & 2.06 & 2.06 & (2.22) & & 2.04 & 2.06 & (\mathbf{2 . 2 5 )} & \\ \mathrm{X}-\mathrm{Sb}(6 \mathrm{Sb}) & 2.91 & (3.11 & 3.22 & 3.33) & 3.03 & (3.30 & 3.35 & 3.42 \\ & & 3.39 & 3.62) & & & 3.51 & 3.65) & \\ \mathrm{X}-\mathrm{X}(4 \mathrm{X}) & 3.72 & (4.33 & 4.46 & 4.46) & 3.79 & (4.37 & 4.40 & 4.40) \\ \mathrm{X}-3 \mathrm{O}(5 \mathrm{O}) & 2.98 & 3.21 & 3.37 & (3.51 & 3.09 & 3.28 & 3.39 & (3.65 \\ & & 3.74) & & & & 3.94) & & \\ \mathrm{O}_{1}-4 \mathrm{X} & 3.51 & 3.74 & & & 3.65 & 3.94 & & \\ \mathrm{O}_{2}-2 \mathrm{X} & 3.21 & 3.37 & & & 3.28 & 3.39 & & \\ \mathrm{O}_{3}-\mathrm{X} & 2.98 & & & & 3.09 & & & \\ \mathrm{O}_{1}-40(60) & 2.63 & 2.64 & (3.09) & & 2.62 & 2.70 & (3.06) & \\ \mathrm{O}_{2}-2 \mathrm{O}(30) & 2.64 & 2.67 & (3.21) & & 2.62 & 2.78 & (3.17) & \\ \mathrm{O}_{3}-30(50) & 2.61 & 2.63 & 2.67 & (3.09 & 2.62 & 2.70 & 2.78 & (3.06 \\ & & 3.21) & & & & 3.17) & & \end{array}$


the $y$-and the $z$-axes lie in the plane of the plates, which supports the proposed structure.

The interatomic distances are given in table 10. It seems rather difficult to make a definite statement on the nature of the antimony bonds, as the oxygen positions, because of the method in which they have been determined are a little uncertain. Now there are two different kinds of antimony atoms, $\mathrm{Sb}_{1}$ and $\mathrm{Sb}_{2}$.

$\mathrm{Sb}_{2}$ is adjacent to two oxygen atoms at 2.03 and $2.06 \mathrm{kX}$ and a third oxygen atom at $2.44 \mathrm{kX}$. Even considering the uncertainty of the oxygen positions, the third distance seems to be too large to indicate an $\mathrm{Sb}-\mathrm{O}$ bond. $\mathrm{Sb}_{2}$ is also close to three chlorine atoms at distances $2.91,3.33$ and $3.62 \mathrm{kX}$ (2.91 $\mathrm{kX}$ is the shortest $\mathrm{Sb}-\mathrm{Cl}$ distance in the structure). This seems to indicate that $\mathrm{Sb}_{2}$ is bound to two oxygen atoms and one chlorine atom at the distance $2.91 \mathrm{kX}$. This would give angles $\mathrm{O}-\mathrm{Sb}-\mathrm{O} 103^{\circ}, \mathrm{O}-\mathrm{Sb}-\mathrm{Cl}$ $84^{\circ}$ and $71^{\circ}$. However, $2.91 \mathrm{kX}$ for the distance $\mathrm{Sb}_{2}-\mathrm{Cl}$ seems rather large for a covalent bond, as the observed $\mathrm{Sb}-\mathrm{Cl}$ distance in $\mathrm{SbCl}_{3}$ is $2.37 \mathrm{kX}^{\mathbf{1}}$. $\mathrm{Sb}_{1}$ has four oxygen atoms at distances $1.89,2.02,2.06$ and $2.22 \mathrm{kX}$ as nearest neighbours. $\mathrm{Sb}_{1}$ is also fairly close to three chlorine atoms at $3.11,3.22,3.39$ $\mathrm{kX}$. If it is assumed that $\mathrm{Sb}_{1}$ is bound only to the nearest three oxygens (1.9$2.1 \mathrm{kX}$ ) valence angles of $83^{\circ}, 84^{\circ}$ and $149^{\circ}$ are obtained, but $149^{\circ}$ seems to be too great a distorsion of a valence angle expected to be $90^{\circ}-100^{\circ}$ (cf. p. 178). If the four oxygen atoms are considered the angles $\mathrm{O}-\mathrm{Sb}-\mathrm{O}$ for nearest neighbours of oxygen are $83^{\circ}, 84^{\circ}, 79^{\circ}, 75^{\circ}$, and the "diagonal» angles $97^{\circ}$ and $149^{\circ}$. The angles $97^{\circ}, 83^{\circ}, 84^{\circ}, 79^{\circ}$, and $75^{\circ}$ are of about the same magnitude as the valence angles of antimony. We can thus combine the "diagonal» angle $97^{\circ}$ with two of the other four angles and obtain two possible valence configurations. One would have the angles $97^{\circ}, 83^{\circ}$, and $75^{\circ}$, and the other the angles $97^{\circ}, 84^{\circ}$, and $79^{\circ}$. From these values there does not seem to be any reason to prefer one set of angles before the other, so here the nature of the bonds has to be left open. In $\mathrm{Sb}_{4} \mathrm{O}_{5} \mathrm{X}_{2}$ the $\mathrm{Sb}-\mathrm{X}$ distances seem to be rather large. This is perhaps not so objectionable, as this is also the case for the $\mathrm{Me}-\mathrm{X}$ distances in the layer structure $\mathrm{Me}_{2} \mathrm{O}_{2} \mathrm{X}^{8}$. In the latter structure the distances $\mathrm{X}-\mathrm{O}$ are also a little large. In $\mathrm{Sb}_{4} \mathrm{O}_{5} \mathrm{Cl}_{2}$, however, there seems to be contact between halogen and oxygen.

Within an antimony-oxygen chain the $\mathrm{Sb}-\mathrm{O}-\mathrm{Sb}$ angles are $147^{\circ}$ and $137^{\circ}$.

It seems as if the antimony bonds in $\mathrm{Sb}_{4} \mathrm{O}_{5} \mathrm{X}_{2}$ may be regarded as intermediate between covalent and ionic binding.

The fact that antimony and oxygen seem to form chains in the structure. of $\mathrm{Sb}_{4} \mathrm{O}_{5} \mathrm{X}_{2}$, may perhaps be of interest when considering the further hydrolysis of $\mathrm{SbCl}_{3}$. According to Cooke ${ }^{11}$ and Lea and Wood ${ }^{12}$ needle-shaped crystals 
are formed on further hydrolysis, Lea and Wood assigned to them the formula $\mathrm{Sb}_{4} \mathrm{O}_{3}(\mathrm{OH})_{5} \mathrm{Cl}$. Crystal needles have also been obtained in the present investigation. A preliminary analysis does not seem to agree with Lea and Wood's formula, but there might of course have been impurities in the present preparations consisting of amorphous or microcrystalline material. It seems clear that they contain some water and less $\mathrm{Cl}$ than $\mathrm{Sb}_{4} \mathrm{O}_{5} \mathrm{Cl}_{2}$. On further hydrolysis the orthorhombic modification of $\mathrm{Sb}_{2} \mathrm{O}_{3}$, containing chains of $\left(\mathrm{Sb}_{2} \mathrm{O}_{3}\right) \infty$ is formed, although this is normally the high temperature modification ${ }^{15}$.

A determination of the crystal structure of the needle-shaped oxychloride seems to be of interest, and will if possible be carried out. An investigation of these and other antimony oxyhalides may perhaps give further knowledge regarding the oxygen positions in these compounds $\left(\mathrm{Sb}_{4} \mathrm{O}_{5} \mathrm{X}_{2}\right)$.

\section{SUMMARY}

The isomorphous compounds $\mathrm{Sb}_{4} \mathrm{O}_{5} \mathrm{Cl}_{2}$ and $\mathrm{Sb}_{4} \mathrm{O}_{5} \mathrm{Br}_{2}$ have been investigated by $\mathrm{X}$-ray crystallographic methods. They are monoclinic, space group $\mathrm{C}_{2 \mathrm{~h}}^{5}$, and the unit cell contains two formula units. Cell dimensions:

$$
\begin{array}{llllll}
a=6.229 & b=5.107 & c=13.50 \mathrm{kX} & \beta=97.27^{\circ} & \text { for } \mathrm{Sb}_{4} \mathrm{O}_{5} \mathrm{Cl}_{2} \\
a=6.593 & b=5.133 & c=13.43 \mathrm{kX} & \beta=97.89^{\circ} & \text { for } \mathrm{Sb}_{4} \mathrm{O}_{5} \mathrm{Br}_{2}
\end{array}
$$

The atomic coordinates are given in table 9.

These compounds form a new structure type. Projections of the structure are given in fig. s 5 and 6. It is a layer structure, in which antimony-oxygen sheets are connected by single halogen sheets. In the antimony-oxygen sheets there seem to be zig-zag chains of antimony and oxygen. There is, of course, some uncertainty in the oxygen positions. Further investigations of the antimony oxyhalides may perhaps give a more complete picture of the coordination of antimony.

My thanks are due to Professor A. Ölander for providing me with laboratory facilities. I also wish to thank Docent L. G. Sillén, who introduced me to X-ray work, who suggested the subject of this investigation, and whose help and advice have been extremely valuable throughout my work.

\section{REFERENCES}

1. Gregg, H. A., Hampson, G. C., Jenkins, G. J., Jones, P. L. F., and Sutton, L. E. Trans. Faraday Soc. 33 (1937) 852.

2. Hassel, O., and Sandbo, A. Z. physik. Chem. B41 (1938) 75. 
3. Byström, A., and Westgren, A. Arkiv Kemi, Mineral. Geol. 17 B no 2.

4. Bozorth, R. M. J.Am. Chem. Soc. 45 (1923) 1621.

5. Buerger, M. J., and Hendricks, S. B. Z. Krist. 98 (1938) 1.

6. Almin, K. E., and Westgren, A. Arkiv Kemi, Mineral. Geol. 17 B no. 22.

7. Sillén, L. G., and Melander, L. Z. Krist. 103 (1941) 420.

8. Sillén, L. G. Z. anorg. allgem. Chem. 242 (1939) 41.

9. Bannister, F. A., and Hey, M. H. Mineralog. Mag. 24 (1935) 49.

10. Sabanejew, Z. Chem. (1871) 204.

11. Cooke, J. P. Proc. Am. Acad. Arts Sci. 13 (1877) 72.

12. Lea, C., and Wood, J. K. J. Chem. Soc. 125 (1924) 137.

13. Sillén, L. G. X-Ray Studies on Oxides and Oxyhalides of Trivalent Bismuth, Stockholm (1940) p. 128.

14. Internationale Tabellen zur Bestimmung von Kristallstrukturen, Berlin (1935).

15. Bloom, M. C., and Buerger, M. J. Z. Krist. 96 (1937) 365.

Received February 6, 1947. 